\title{
New dragonflies and damselflies (Odonata) from the late Oligocene of Enspel (Rhineland-Palatinate, SW Germany)
}

\author{
André Nel, Markus J. Poschmann, and Sonja Wedmann
}

\begin{abstract}
We describe 10 fossils of dragonfly wings and one damselfly from bituminous pelites of the late Oligocene crater lake of Enspel/Westerwald. These represent two species of Aeshnidae, one species of Gomphidae, one possible stem Libellulidae, and one species of stem Sieblosiidae. The presence of one further undetermined species of crown Libellulidae can be inferred from a well-preserved naiad. Together with an earlier described wing of Macromiidae and a naiad figured herein and possibly attributable to the family Lestidae, the Enspel biota at least comprised eight different morphotypes of Odonata. We propose three new species, Epiaeschna wisseri sp. nov. (Aeshnidae), Ictinogomphus engelorum sp. nov. (Gomphidae), and Oligolestes stoeffelensis sp. nov. (Sieblosiidae), based on wing venation. The lateral position of the body and the rotated head of the holotype of Oligolestes stoeffelensis sp. nov. confirm that the Sieblosiidae had zygopteran hammer-shaped heads. This quite diverse odonate fauna is typical of Oligocene European paleolakes and suggests a water oxygenation suitable for the development of the aquatic naiads that lasted for longer periods and niche partitioning among the adult animals in a well-structured palaeo-ecosystem.
\end{abstract}

André Nel. Institut de Systématique, Evolution, Biodiversité, ISYEB, UMR 7205, CNRS, MNHN, UPMC, EPHE, Muséum national d'Histoire naturelle, Sorbonne Universités, 57 rue Cuvier, CP 50, Entomologie, F75005, Paris, France. Corresponding author. andre.nel@mnhn.fr; https://orcid.org/0000-0002-4241-7651 Markus J. Poschmann. Generaldirektion Kulturelles Erbe Rheinland-Pfalz, Direktion Landesarchäologie/ Erdgeschichte, Niederberger Höhe 1, D-56077 Koblenz, Germany. markus.poschmann@gdke.rlp.de; https://orcid.org/0000-0001-9710-1673

Sonja Wedmann. Senckenberg Forschungsinstitut und Naturmuseum, Forschungsstation Grube Messel, Markstraße 35, D-64409 Messel, Germany. sonja.wedmann@senckenberg.de; https://orcid.org/00000002-9778-4125

Keywords: Paleogene; Aeshnidae; Libellulidae; Gomphidae; Sieblosiidae; new species; naiads; adults Submission: 1 September 2020. Acceptance: 26 November 2020.

http://zoobank.org/7DBD6C05-FA99-45CB-82E8-0C9CD7436EE3

Nel, André, Poschmann, Markus J., and Wedmann, Sonja. 2020. New dragonflies and damselflies (Odonata) from the late Oligocene of Enspel (Rhineland-Palatinate, SW Germany). Palaeontologia Electronica, 23(3):a59. https://doi.org/10.26879/1126 palaeo-electronica.org/content/2020/3250-odonata-from-enspel

Copyright: December 2020 Paleontological Society.

This is an open access article distributed under the terms of Attribution-NonCommercial-ShareAlike 4.0 International (CC BY-NC-SA 4.0 ), which permits users to copy and redistribute the material in any medium or format, provided it is not used for commercial purposes and the original author and source are credited, with indications if any changes are made.

creativecommons.org/licenses/by-nc-sa/4.0/ 


\section{INTRODUCTION}

The black pelitic sediments or 'oilshales' of Fossillagerstätte Enspel were deposited in a crater lake (e.g., Schindler and Wuttke, 2010, 2015) with a late Oligocene age of 24.79-24.56 Ma (Mertz et al., 2007). Scientific excavations by the former Landesamt für Denkmalpflege/Referat Erdgeschichte (now part of the Generaldirektion Kulturelles Erbe Rheinland-Pfalz) from 1990 until 2015 yielded rich fossil associations including plants, invertebrates, and both aquatic and terrestrial vertebrates (for an overview see Poschmann et al., 2010). More than 12,000 specimens of fossil arthropods were recovered, mostly insects (see Wedmann, 2000; Wedmann et al., 2010 for overviews).

The Odonata are relatively rare, represented by a total of about 70 fossils, roughly 0.6 per cent of all insect finds. Of those, 12 fossils of Anisoptera are wings derived from adult animals, one specimen is the adult Zygoptera: Sieblosiidae described herein, and the rest represent nymphal stages or exuviae thereof attributable to various odonate families (Wedmann, 2000; Wedmann et al., 2010; Brockhaus et al., 2020). One of these wings is attributable to the family Macromiidae (Brockhaus et al., 2020), and another one is too incomplete to allow further conclusions. Here, we describe the remaining 10 wings belonging to the families Aeshnidae, Gomphidae, and Libellulidae, along with the Sieblosiidae fossil.

\section{MATERIAL AND METHODS}

The fossils from Enspel were excavated during digging campaigns conducted by the Generaldirektion Kulturelles Erbe Rheinland-Pfalz, Direktion Landesarchäologie/Erdgeschichte and are part of the State Collection of Natural History of Rhineland-Palatinate at the Natural History Museum Mainz. The specimens are stored in plastic boxes filled with glycerin and were photographed immersed in water using a Canon EOS 600D SLR camera equipped with a Canon EFS $60 \mathrm{~mm}$ macro lens. Stacking software CombineZP (by Alan Hadley) served to combine photographs with differing focal planes in order to enhance depth of field. Drawings were made from enlarged photographs or directly from the specimens using a camera lucida attachment on a Leica MZ125 microscope.

We follow the higher classification of fossil and extant Odonatoptera based on the phylogenetic system of Bechly (1996, 2016), and employ the dragonfly wing venation nomenclature of Riek and Kukalová-Peck (1984), as modified by Nel et al. (1993), Bechly (1996), and Jacquelin et al. (2018).

Venation abbreviations are as follows: AA anterior anal; Arc arculus; Ax primary antenodal crossvein; $\mathrm{Bqs}$ crossveins in space between base of IR2, RP1/2; C costa; CuA anterior cubitus; CuP posterior cubitus; IR intercalary radial vein; MAa anterior branch of anterior media; MAb posterior branch of anterior media; MP posterior media; Mspl supplementary median vein; 'O' oblique vein between IR2 and RP2 distal of subnodus; Pt pterostigma; RA anterior radius; RP posterior radius; Rspl supplementary radial vein; Sn subnodal crossvein; ScP posterior subcostal; tspl trigonal planate.

\section{SYSTEMATIC PALAEONTOLOGY}

\author{
Class INSECTA Linné, 1758 \\ Order ODONATA Fabricius, 1793 \\ Family AESHNIDAE Leach, 1815
}

Genus OLIGAESCHNA Piton and Théobald, 1939

Type species. Oligaeschna jungi Piton and Théobald, 1939 (late Oligocene-Early Miocene, Puy-du-Mur, Center of France, Gaudant, 1993).

Other species. Oligaeschna wedmanni $\mathrm{Nel}$ and Fleck, 2014 (latest Eocene, Isle of Wight, UK), Oligaeschna separata (Scudder, 1890) (latest Eocene, Florissant, Colorado, USA), Oligaeschna lapidaria (Cockerell and Counts, 1913 in Cockerell, 1913) (latest Eocene, Florissant, Colorado, USA), Oligaeschna cf. jungi (Rupelian, Enspel, Germany), Oligaeschna cf. jungi (Rupelian, Céreste, Southern France), Oligaeschna palaeocoerulea (Timon-David, 1946) (Rupelian, Gypsum Mine, Camoins-les-Bains, Southern France; Rousset et al., 1996), Oligaeschna kvaceki Prokop et al., 2007 (Rupelian-Chattian, Moravia, Czech Republic), Oligaeschna ashutasica (Martynov, 1929) (Chattian, Mount Ashutas, river Irtysh, Kazakhstan), Oligaeschna saurai Peñalver et al., 1996 (early Miocene, Ribesalbes, Spain), Oligaeschna bulgariensis Nel et al., 2016 (middle Miocene, Satovcha Graben, SW Bulgaria).

Oligaeschna cf. jungi Piton and Théobald, 1939

Figures 1-4

Material. PE 2005/5032-LS a, b (part and counterpart of two forewings attached to fragments of thorax), specimen PE 2000/5005-LS a, b (part and counterpart of a nearly complete forewing), specimen Enspel PE 1995/7217-LS (a complete forewing), specimen PE 1995/9174-LS (basal two-third 

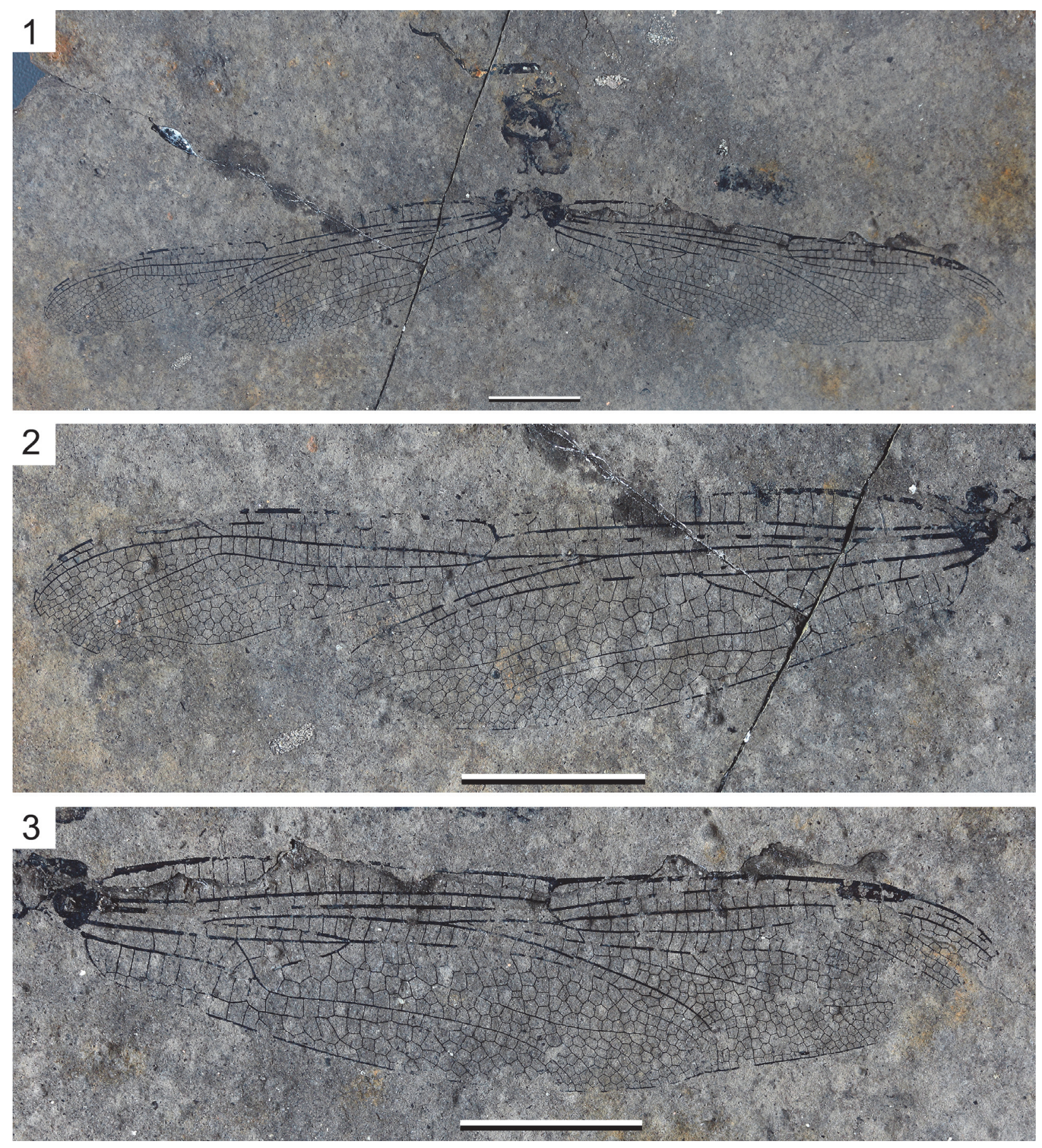

FIGURE 1. Oligaeschna cf. jungi, specimen PE 2005/5032-LS a. 1, Overall view of fossil with two forewings, remains of the thorax, and one leg; 2, Left forewing enlarged; 3, Right forewing enlarged. Scale bars are $10 \mathrm{~mm}$.

of a hind wing), all stored at the State Collection of Natural History of Rhineland-Palatinate.

Description. PE 2005/5032-LS a (Figures 1.1-3, 3.1-2): Forewing, hyaline, $50.0 \mathrm{~mm}$ long, $11.3 \mathrm{~mm}$ wide; distance from base to arculus $5.2 \mathrm{~mm}$; from arculus to nodus $19.3 \mathrm{~mm}$; from nodus to pterostigma $15.3 \mathrm{~mm}$, from nodus to wing apex
$25.2 \mathrm{~mm}$; pterostigma $4.3 \mathrm{~mm}$ long, $0.8 \mathrm{~mm}$ wide, covering five cells; pterostigmal brace elongate, distinctly oblique and sigmoidal; 16 secondary antenodal crossveins distal of Ax2 and four between $A \times 2$ and $A \times 1$; Ax2 at level of mid part of discoidal triangle; Ax1 well basal to arculus; arculus strongly angled; 14 antesubnodal crossveins; at 
Nel, Poschmann, \& Wedmann: Odonata from Enspel
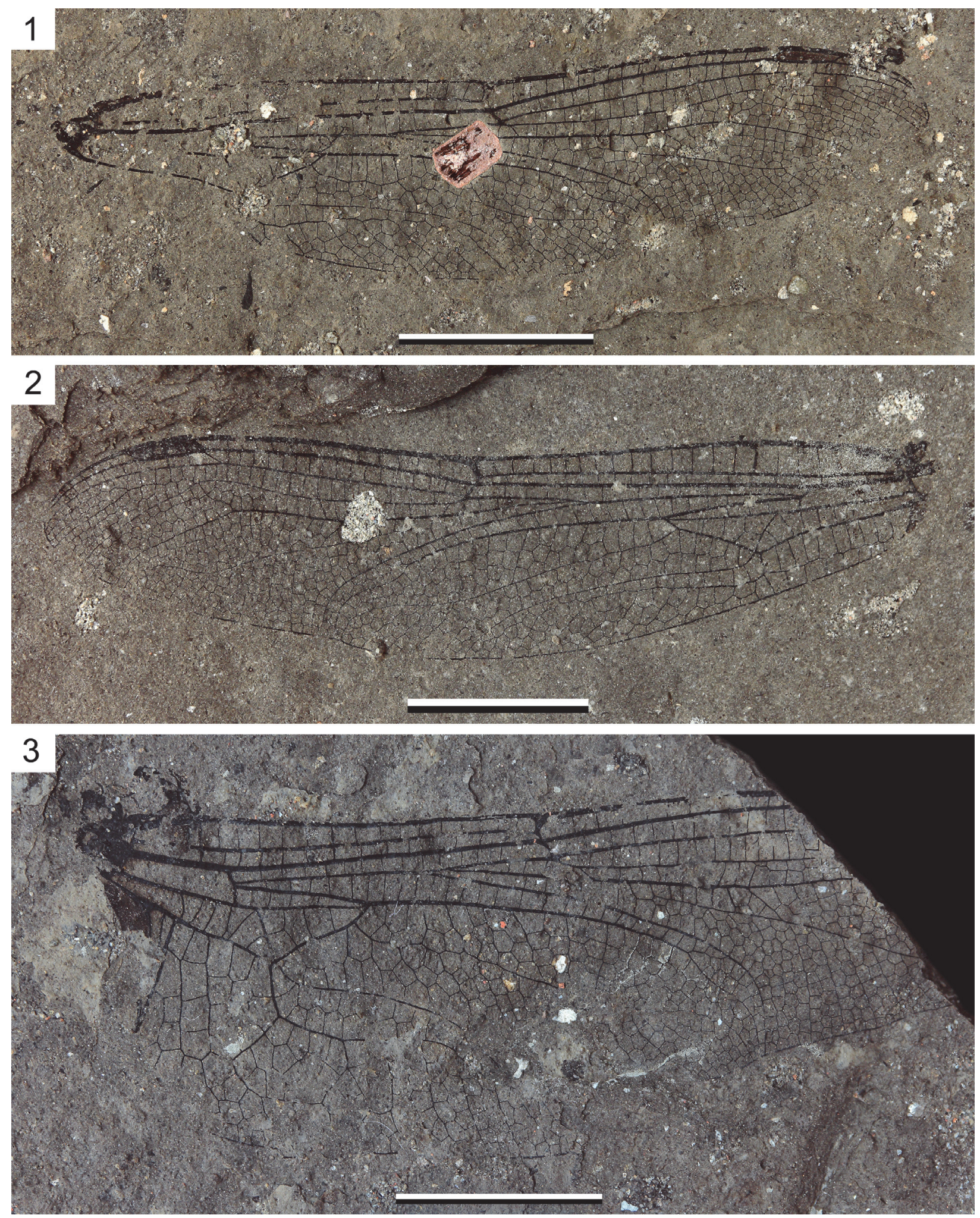

FIGURE 2. Oligaeschna cf. jungi. 1, PE 2000/5000-LS a, forewing; 2, PE 1995/7217-LS, forewing; 3, PE 1995/9174LS, hindwing. Scale bars are $10 \mathrm{~mm}$. 

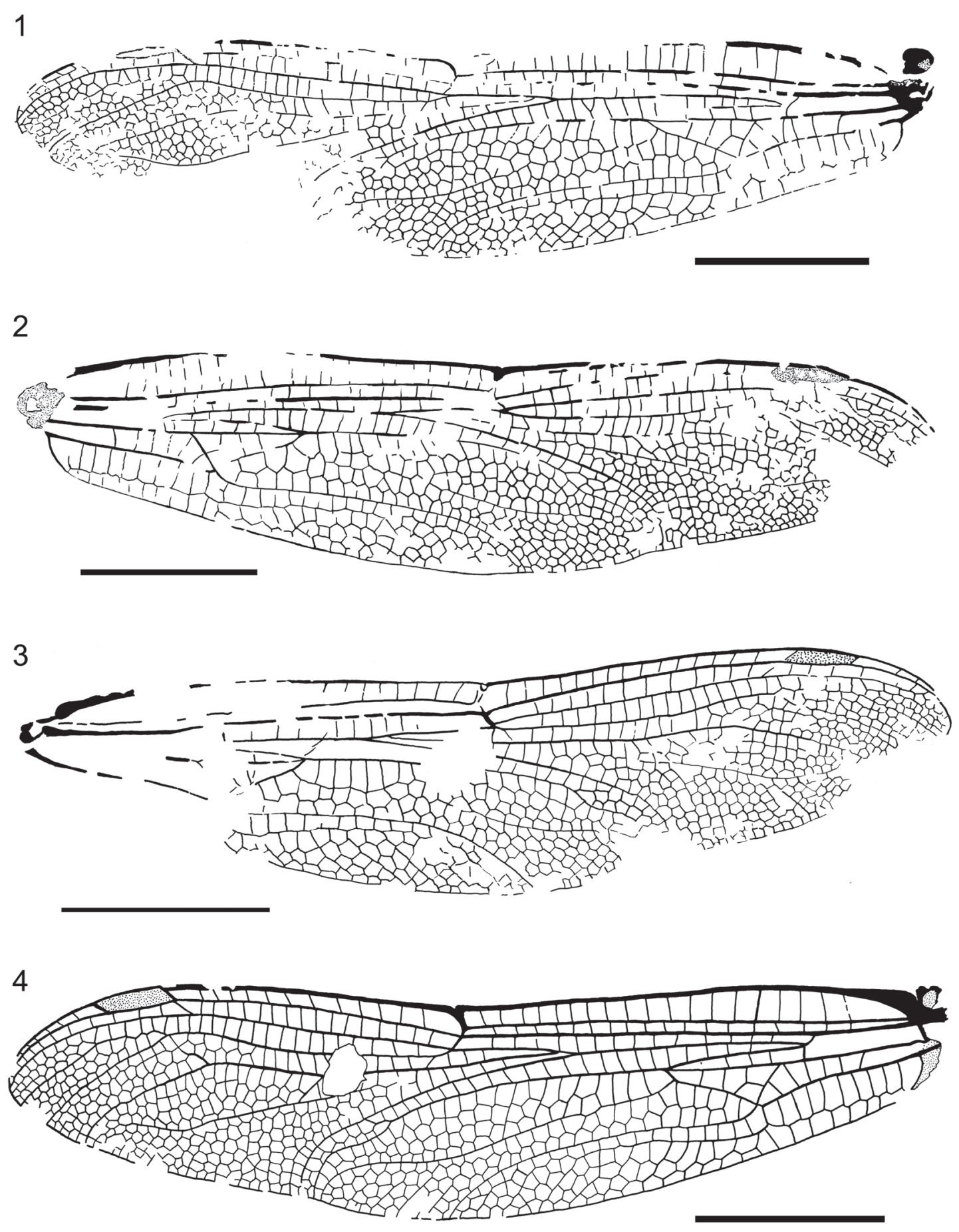

FIGURE 3. Oligaeschna cf. jungi, interpretative drawings of wings. 1, PE 2005/5032-LS a, left forewing; 2, PE 2005/ 5032-LS a, right forewing; 3, PE 2000/5000-LS a, forewing; 4, PE 1995/7217-LS, forewing. Scale bars are $10 \mathrm{~mm}$.

most 14 postnodal crossveins and 17 postsubnodals; hypertriangle elongate, with four crossveins; discoidal triangle elongate, divided into five cells; three rows of cells in basal part of postdiscoidal area; median space free; submedian space with five crossveins plus CuP stronger than other crossveins; Mspl strongly curved, four rows of cells between Mspl and MA; four Bq crossveins; oblique vein ' $O$ ' one cell distal of base of RP2; MA with a smooth curve opposite base of Rspl; beyond this 


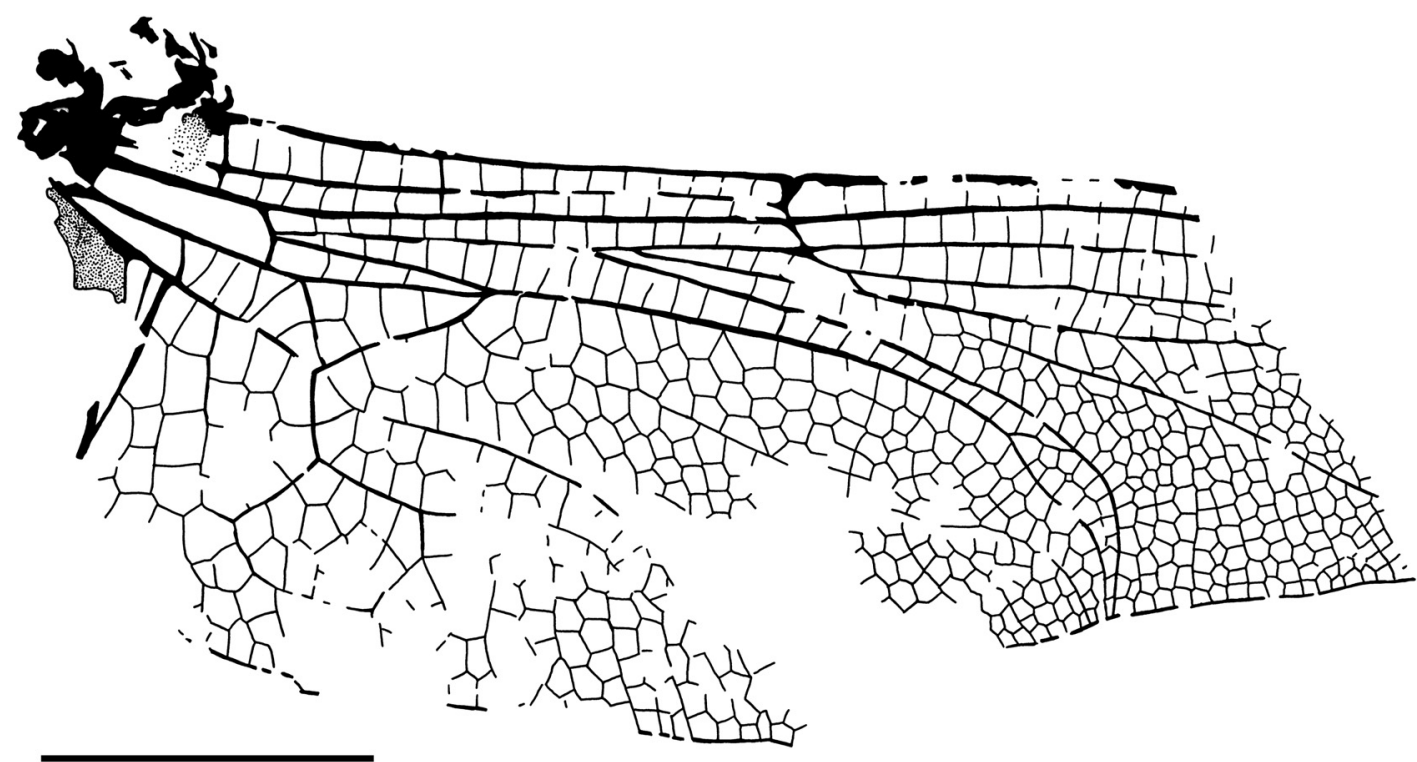

FIGURE 4. Oligaeschna cf. jungi, interpretative drawing of hind wing PE 1995/9174-LS. Scale bar is $10 \mathrm{~mm}$.

level, two rows of cells between MA and RP3/4; Rspl strongly curved, with four rows of cells between it and IR2; IR2 unforked, with a posterior curve; four rows of cells between IR2 and RP2 in broadest part; RP2 distinctly but smoothly curved at level of pterostigma.

Specimen PE 2000/5005-LS a (Figures 2.1, 3.3): Forewing, hyaline, $45.1 \mathrm{~mm}$ long, $10.3 \mathrm{~mm}$ wide; distance from base to arculus $7.2 \mathrm{~mm}$; from arculus to nodus $14.0 \mathrm{~mm}$; from nodus to pterostigma 14.8 $\mathrm{mm}$, from nodus to wing apex $22.7 \mathrm{~mm}$; pterostigma $3.9 \mathrm{~mm}$ long, $0.8 \mathrm{~mm}$ wide, covering four cells; pterostigmal brace elongate, distinctly oblique and sigmoidal; exact number of secondary antenodal crossveins unknown $A \times 2$ at level of mid part of discoidal triangle; $A \times 1$ well basal to arculus; arculus strongly angled; 12-13 antesubnodal crossveins; 13 postnodal crossveins and 12 postsubnodals; hypertriangle elongate; discoidal triangle elongate, divided into five cells; three rows of cells in basal part of postdiscoidal area; median space free; Mspl strongly curved, four rows of cells between $\mathrm{Mspl}$ and $\mathrm{MA}$; three $\mathrm{Bq}$ crossveins; oblique vein ' $\mathrm{O}$ ' one cell distal of base of RP2; MA with a smooth curve opposite base of Rspl; beyond this level, two rows of cells between MA and RP3/ 4; Rspl strongly curved, with four rows of cells between it and IR2; IR2 unforked and with a posterior curve; four rows of cells between IR2 and RP2 in broadest part; RP2 distinctly but smoothly curved at level of pterostigma.
Specimen PE 1995/7217-LS (Figures 2.2, 3.4): Forewing, hyaline, $48.8 \mathrm{~mm}$ long, $11.5 \mathrm{~mm}$ wide; distance from base to arculus $5.5 \mathrm{~mm}$; from arculus to nodus $18.9 \mathrm{~mm}$; from nodus to pterostigma 14.9 $\mathrm{mm}$, from nodus to wing apex $24.2 \mathrm{~mm}$; pterostigma $4.2 \mathrm{~mm}$ long, $0.8 \mathrm{~mm}$ wide, covering three cells; pterostigmal brace elongate, distinctly oblique and sigmoidal; 14 secondary antenodal crossveins distal of $A \times 2$ and four between $A \times 2$ and $A \times 1 ; A \times 2$ at level of mid part of discoidal triangle; Ax1 well basal to arculus; arculus strongly angled; 14 antesubnodal crossveins; 12 postnodal crossveins and 16 postsubnodals; hypertriangle elongate, with four crossveins; discoidal triangle elongate, divided into five cells; three rows of cells in basal part of postdiscoidal area; median space free; submedian space with three crossveins plus CuP stronger than other crossveins; Mspl strongly curved, four rows of cells between Mspl and MA; three Bq crossveins; oblique vein 'O' one cell distal of base of RP2; MA with a smooth curve opposite base of Rspl; beyond this level, two rows of cells between MA and RP3/4; Rspl strongly curved, with four rows of cells between it and IR2; IR2 unforked but with a rudiment of asymetrical anterior branch, and with a posterior curve; four rows of cells between IR2 and RP2 in broadest part; RP2 distinctly but smoothly curved at level of pterostigma. Specimen PE 1995/9174-LS (Figures 2.3, 4). Basal two-third of a hind wing; hyaline; preserved part $42.2 \mathrm{~mm}$ long, $16.7 \mathrm{~mm}$ wide; distance between base and arculus $6.4 \mathrm{~mm}$, between arcu- 
lus and nodus $15.3 \mathrm{~mm}$; two primary antenodal crossveins $A \times 1$ and $A \times 2$ visible, with no secondary crossvein basal of $A \times 1$, five between $A \times 1$ and $A \times 2$, between $C$ and $S c P$; nine antenodal crossveins distal of $A \times 2$, distance between base and $A \times 15.0$ $\mathrm{mm}$, between $\mathrm{Ax} 1$ and $\mathrm{Ax} 26.4 \mathrm{~mm}$; median space free; four crossveins in submedian area; arculus between $A x 1$ and $A \times 2$, slightly closer to $A x 1$; RP and MA nearly meeting at their base in arculus; posterior part of arculus not aligned with anterior part; hypertriangle crossed by four veins; discoidal triangle elongate, divided into five cells; $4-5$ rows of cells in basal part of postdiscoidal area; convex trigonal planate tspl in postdiscoidal area rather well-defined but short and zigzagged; Mspl long, with a strong concave bend, and with four rows of cells between it and MA; MA and RP3/4 not parallel in their distal part, and MA with a concave bend before wing margin, two rows of cells between MA and RP3/4; base of RP2 aligned with subnodus; oblique vein 'O' one cell distal of base of RP2; RP2 more or less parallel with IR2; Rspl distinctly curved, with four rows of cells between it and IR2; anal angle strongly angular (male); membranule broad and darkened; anal loop closed, welldefined, broad and large, $3.0 \mathrm{~mm}$ long and $5.5 \mathrm{~mm}$ wide, divided into nine cells; two rows of cells between MP and CuAa between their base and nodus level; CuA with posterior branches that define groups of cells, and six rows of cells between it and posterior wing margin.

Remarks. These fossils have all the synapomorphies of the family Aeshnidae as defined by Bechly (1996), i.e., 'aeshnid bulla' in distal part of MA; Rspl distinctly curved with more than one row of cells between it and IR2, and area in between divided by oblique intercalary veins; three rows of cells in basal part of postdiscoidal area between level of distal angle of discoidal triangle and level of midfork; hypertriangle traversed by at least three crossveins. Following the study of von Ellenrieder (2002), these fossils would fall near the extant Oplonaeschna de Selys-Longchamps, 1883, from the shape of the veins Rspl, IR2, and RP2. The closest modern genera differ either in the narrower area between Rspl and IR2 with less than three rows of cells, or in the forked IR2 (see Martin, 1908-1909, 1911). The fossils differ from the extant genus Oplonaeschna in the longer pterostigma covering three cells or more and in the presence of three rows of cells in basal part of postdiscoidal areas instead of two. The general pattern of venation fits quite well with the Cenozoic genus Oligaeschna Piton and Théobald, 1939 (revised in
$\mathrm{Nel}$ et al., 1994). The Oligocene genus Kvacekia Prokop and Nel, 2002, is also closely related to Oligaeschna and Oplonaeschna, but it is characterized by a pterostigma covering 5-6 cells (five in our fossils), and by five rows of cells in the area between IR2 and RP2 (four in our fossil and 3-4 in Oligaeschna) (Prokop and Nel, 2002).

Apart from weak differences in wing sizes and proportions, these wings are very similar and can be attributed to the same species, even if there is some uncertainty in the presence vs. absence of a fork of IR2 for the hind wing specimen PE 1995/ 9174-LS. Its preserved part of venation fits quite well with that of the hind wing of the type series of Oligaeschna jungi and with the complete hind wing from Céreste attributed to this species by Nel et al. (2005c). Thus, we propose to attribute these fossils to Oligaeschna, in accordance with Wedmann (2000: fig. 5) and Wedmann et al. (2010: fig. 6d) who indicated that it is probably Oligaeschna jungi'.

The genus Oligaeschna comprises nine described species from Oligocene and Miocene deposits in North American and Eurasia. Oligaeschna bulgariensis has much more postnodals (21). Oligaeschna cf. jungi shares with O. palaeocoerulea the presence of four rows of cells between IR2 and RP2, five cells below the pterostigma, 14 postnodal crossveins and 17 postsubnodals, close distances between nodus and pterostigma (25.2 $\mathrm{mm}$ in Oligaeschna cf. jungi and $28.3 \mathrm{~mm}$ in the type of $O$. palaeocoerulea). But $O$. palaeocoerulea has 10 rows of cells between IR2 and RP2 along wing margin, instead of five in Oligaeschna cf. jungi. Oligaeschna kvaceki is based on a hind wing of same length as our fossil and a pterostigma covering five cells, five rows of cells between IR2 and RP2 along wing margin, as in Oligaeschna cf. jungi. But it has 17 postnodals instead of 12-14 in Oligaeschna cf. jungi and a shorter pterostigmal brace (Prokop et al., 2007). Oligaeschna lapidaria has a pterostigma covering three cells and a shorter pterostigmal brace (Cockerell, 1913). Oligaeschna saurai also has a pterostigma covering three cells, a shorter pterostigmal brace, and five rows of cells between Rspl and IR2 (Peñalver et al., 1996). Oligaeschna wedmanni has a forewing of the same size as Oligaeschna cf. jungi, but five rows of cells between IR2 and RP2, and only three rows of cells between Mspl and MAa, unlike Oligaeschna cf. jungi (Nel and Fleck, 2014). Oligaeschna ashutasica, based on a hind wing, has three rows of cells between RP2 and IR2, and three rows of cells between MAa 
and Mspl (Martynov, 1929). Oligaeschna separata has a forewing $44 \mathrm{~mm}$ long and 13 postnodals (Scudder, 1890).

Oligaeschna cf. jungi differs from the type series of Oligaeschna jungi in the presence of four rows of cells between IR2 and RP2 instead of five, pterostigma covering 3-5 cells instead of three, and wing lengths $45-50 \mathrm{~mm}$ instead of ca. $55-56$ $\mathrm{mm}$ in $\mathrm{O}$. jungi. These differences would hardly support a species separation between the two populations from France and Germany.

These fossil wings are of interest to show the intraspecific variability, which is rather important in the genus Oligaeschna. Nevertheless, the character 'presence of three rows of cells in basal part of the forewing postdiscoidal area' and 'presence of 4-5 rows of cells in basal part of the hind wing postdiscoidal area' appear stable enough to justify the separation between the two genera Oligaeschna and Oplonaeschna.

\section{Genus EPIAESCHNA Hagen, 1877}

Type species. Aeshna heros Fabricius, 1798 (Recent, Nearctic).

Other species. Epiaeschna gossi (Campion, 1916) (middle-late Eocene, UK), Epiaeschna magnifica (Martynov, 1929) (late Oligocene, Kazakhstan), Epiaeschna wisseri sp. nov. (late Oligocene, Germany), Epiaeschna pseudoheros $\mathrm{Nel}$ and Petrulevičius, 2010 (latest Oligocene, France), Epiaeschna stauropolitana Martynov, 1927 (middle Miocene, Crimea), Epiaeschna matutina (Zhang, 1989) (middle Miocene, China).

\section{Epiaeschna wisseri sp. nov.}

Figures 5-6

\section{zoobank.org/5EE44E2C-34D4-407B-BAAD-711D7093E69E}

Type material. Holotype PE 2000/5355-LS a, b (part and counterpart of a nearly complete hind wing, parts of basal fourth of wing missing), stored at the State Collection of Natural History of Rhineland-Palatinate.

Additional material. PE 1997/6211-LS a, b (part and counterpart of basal two-third of a hind wing), stored at the State Collection of Natural History of Rhineland-Palatinate.

Diagnosis. Hind wing characters only. Wing darkened; fork of IR2 far from pterostigma; base of IR1 opposite base of pterostigma; pterostigma covering four cells, 18 postnodals; area between Rspl and IR2 with three rows of cells.

Etymology. Named for Dieter Wisser, mayor of Enspel, for his continuous support of the excavations.
Description. Holotype PE 2000/5355-LS a (Figures 5.1, 6.1): Hind wing darkened, $58.1 \mathrm{~mm}$ long, $16.9 \mathrm{~mm}$ wide, ratio length/width 3.4 ; distance between base and arculus $5.4 \mathrm{~mm}$, between arculus and nodus $18.0 \mathrm{~mm}$, between nodus and pterostigma $23.0 \mathrm{~mm}$, between pterostigma and apex $7.0 \mathrm{~mm}$; pterostigma $5.3 \mathrm{~mm}$ long, $0.8 \mathrm{~mm}$ wide, covering four cells; pterostigmal brace present, distinctly oblique, and aligned with basal margin of pterostigma; primary antenodal crossveins not preserved, 11 secondary crossveins visible; 18 postnodal crossveins not aligned with 17 postsubnodals; median space free; CuP not visible; RP and MA meeting at their base in arculus; posterior part of arculus not aligned with anterior part; hypertriangle crossed by three veins, rather short, 7.3 $\mathrm{mm}$ long, $0.9 \mathrm{~mm}$ wide; discoidal triangle elongate but rather broad, $6.9 \mathrm{~mm}$ long, $1.1 \mathrm{~mm}$ wide, crossed by three transverse veins; trigonal planate not preserved; Mspl partly preserved, weakly zigzagged, without strong concave bend, and with three rows of cells between it and MAa; MAa and RP3/4 parallel and MAa with no concave bend before wing margin, two rows of cells between MA and RP3/4 in distal end; base of RP2 aligned with subnodus; oblique vein ' $O$ ' one cell distal of base of RP2; distal fork of IR2 symmetrical, $6.1 \mathrm{~mm}$ basal of level of pterostigma, with 4-5 rows of cells in area between its branches; RP2 parallel with anterior branch of IR2, making a distinct curve; base of IR1 one cell distal of pterostigmal brace; Rspl straight, with three rows of cells between it and IR2; anal loop only partly visible; CuA poorly preserved, probably with 5-6 posterior branches and 6-7 rows of cells between it and posterior wing margin.

Additional specimen PE 1997/6211-LS a (Figures 5.2, 6.2): Hind wing, apparently hyaline, $13.6 \mathrm{~mm}$ wide, preserved part $28.0 \mathrm{~mm}$ long; distance between base and arculus $4.2 \mathrm{~mm}$, between arculus and nodus $12.8 \mathrm{~mm}$, pterostigma not preserved; median space free; RP and MA meeting at their base in arculus; posterior part of arculus not aligned with anterior part; hypertriangle crossed; discoidal triangle elongate but rather broad, crossed by three transverse veins; trigonal planate weak; Mspl weakly curved, with two rows of cells between it and MAa; MAa and RP3/4 parallel and MAa with no concave bend before wing margin, two rows of cells between MA and RP3/4 in distal end; base of RP2 aligned with subnodus; oblique vein 'O' one cell distal of base of RP2; distal fork of IR2 not preserved; RP2 parallel with IR2; Rspl straight, with two rows of cells between it and IR2; 

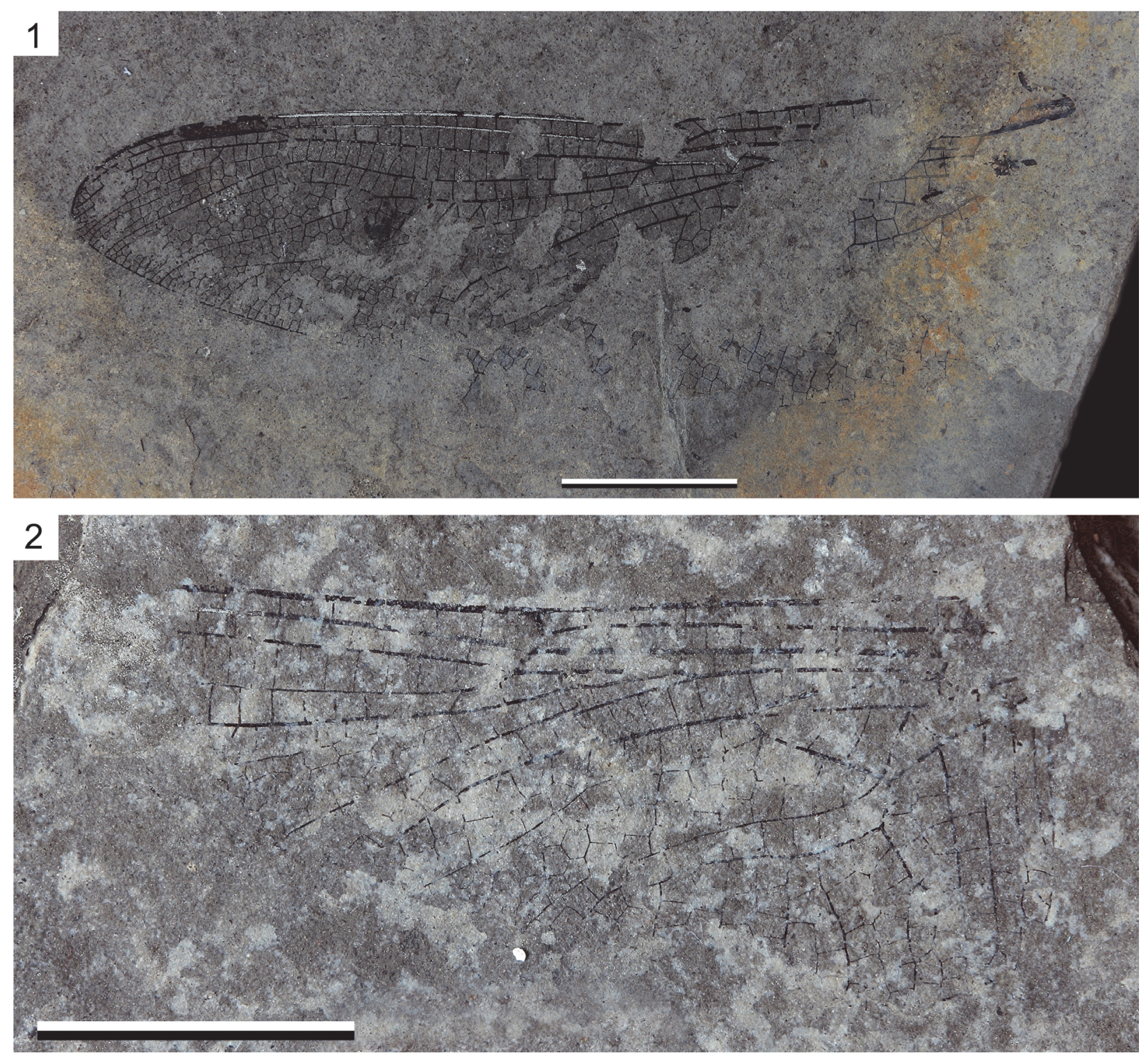

FIGURE 5. Epiaeschna wisseri sp. nov. 1, holotype, PE 2000/5355-LS a; 2, putative specimen PE 1997/6211-LS a, hind wing. Scale bars are $10 \mathrm{~mm}$.

anal loop with two rows of cells; CuA with six posterior branches and seven rows of cells between it and posterior wing margin.

Remarks. Specimen PE 2000/5355-LS (Figures $5.1,6.1$; a hind wing because of the broad cubitoanal area) is extremely similar to those of the Oligocene-Miocene hawker dragonflies of Eurasia described or revised in $\mathrm{Nel}$ and Petrulevičius (2010) and $\mathrm{Li}$ et al. (2011), and attributed to the genus Epiaeschna. Epiaeschna heros differs from all fossil species in the shorter and less oblique pterostigmal brace and narrower area between IR2 and Rspl with only two rows of cells (Garrison et al., 2006). Epiaeschna wisseri sp. nov. differs from Epiaeschna pseudoheros in the base of IR1 being opposite to the base of the pterostigma instead of being opposite to its middle, the pterostigma covering four cells instead of five, and the presence of only 18 postnodals instead of 20 . The pterostigma of Epiaeschna stauropolitana covers seven cells, and its area between Rspl and IR2 has two rows of cells instead of three as in Epiaeschna wisseri sp. nov. Epiaeschna magnifica also has a pterostigma covering 7-8 cells, and its base of IR1 is well basal of the pterostigmal brace. Epiaeschna gossi has much more postnodals than Epiaeschna wisseri sp. nov. and a very long and oblique pterostigmal brace. Epiaeschna matutina has 21 postnodals in a slightly shorter wing (55.6 mm long, instead of 58.1 $\mathrm{mm}$ in Epiaeschna wisseri sp. nov.). Otherwise, the 
1

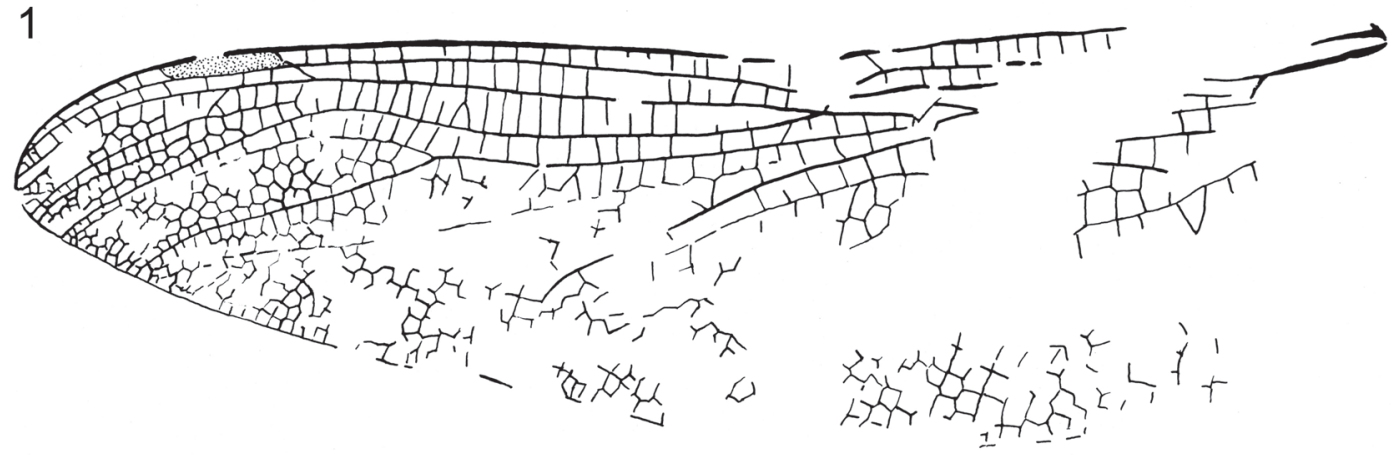

2

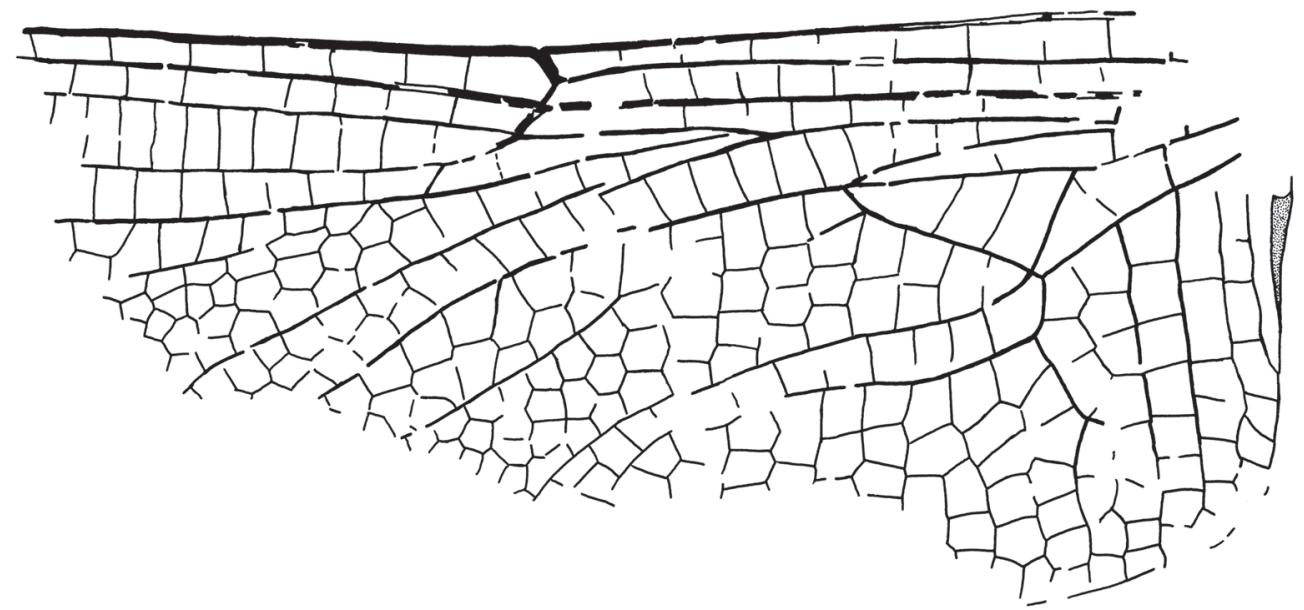

FIGURE 6. Epiaeschna wisseri sp. nov., interpretative drawings of hind wings. 1, holotype, PE 2000/5355-LS a; 2 , putative conspecific specimen, PE 1997/6211-LS a, female hind wing. Scale bars are $10 \mathrm{~mm}$.

venations of E. matutina and Epiaeschna wisseri sp. nov. are very similar, even in their darkened wings and the ratios wing length/wing width ( $\mathrm{Li}$ et al., 2011). The most significant difference is in the position of the fork of IR2, being farther from the pterostigma in Epiaeschna wisseri sp. nov. than in E. matutina [viz. $6.1 \mathrm{~mm}$ basal of level of base of pterostigma in Epiaeschna wisseri sp. nov., while it is $5.1 \mathrm{~mm}$ in E. matutina, that is ratio (wing length/ distance between Pt and fork of IR2) $=9.5$ in Epiaeschna wisseri sp. nov. vs. 10.9 in E. matutina].

Specimen PE 1997/6211-LS (Figures 5.2, 6.2) is also a hind wing (female, because of the absence of anal angle and triangle), smaller than holotype PE 2000/5355-LS and with a wing membrane apparently hyaline. But these differences are compatible with intraspecific variations and taphonomic biases. Despite the lack of information on the fork of IR2, the venation of the preserved part fits well with that of the extant and fossil Epiaeschna spp., especially in the narrow anal loop with two rows of cells (see Garrison et al., 2006: fig. 247). Thus, we tentatively attribute it to Epiaeschna wisseri sp. nov., but with some doubt, so that we do not consider it as a paratype.

\section{Family LIBELLULIDAE Leach, 1815 (stem group representative?) \\ Genus and species undetermined}

Figures 7-8

Material. Specimen PE 2001/5195-LS (incomplete hind wing with only anterior half preserved), stored at the State Collection of Natural History of Rhineland-Palatinate.

Description. Hind wing, hyaline; length of preserved part $28.0 \mathrm{~mm}$; width $7.0 \mathrm{~mm}$; distance from base to arculus $4.0 \mathrm{~mm}$, from arculus to nodus 9.0 $\mathrm{mm}$, from nodus to pterostigma $13.6 \mathrm{~mm}$; 


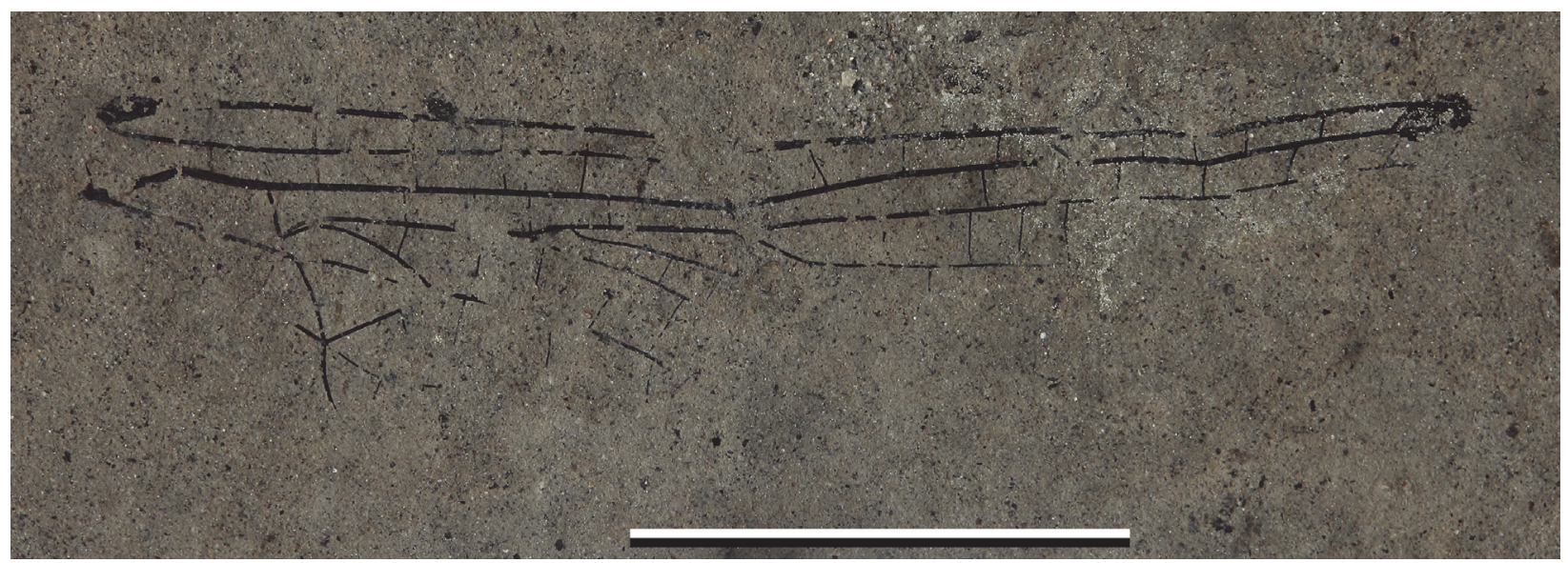

FIGURE 7. Probably a stem-Libellulidae, PE 2001/5195-LS, hind wing. Scale bar is $10 \mathrm{~mm}$.

pterostigma incomplete but rather elongate; pterostigmal brace weak and not aligned with basal side of pterostigma; $A \times 1, A x 2$, and first secondary antenodal of same shape with a membrane between them, C, ScP, and RA; two more distal antenodals complete but without membrane, last antenodal apparently incomplete, only present between ScP and RA; arculus midway between $A x 1$ and Ax2; sectors of arculus not stalked but joined at base; four antensubnodal crossveins, the last one being distal of base of IR2; hypertriangle and discoidal triangle free; PsA not oblique and weak; eight postnodal crossveins, not aligned with the postsubnodals, the two basal postsubnodals absent; no 'libellulid oblique crossvein'; oblique crossvein ' $\mathrm{O}$ ' two cells distal of subnodus (Figures 7-8).

Remarks. This hind wing is attributable to the clade Libellulida Bechly, 1996, because of the following characters: hind wing discoidal triangle recessed to the level of the arculus; the first secondary crossvein has a membrane between it, $\mathrm{C}$,
$\mathrm{ScP}$, and RA, as for the two primary antenodal crossveins $A \times 1$ and $A \times 2$. The absence of a 'libellulid oblique crossvein' between RP1 and RP2 excludes affinities with the Urothemistidae Lieftinck, 1954. But even if the two more distal secondary antenodals are complete (alignments of the antenodals of first row with those of second row), but they lack the membrane of the three more basal antenodals, and the sectors of arculus are not stalked but only joined at their base, which are symplesiomorphies of the Libellulidae. Even if they share the character 'sectors of arculus not stalked but basally joined', our new fossil does not fit well in the Eocene family Urolibellulidae, belonging to the stem Libellulida, because the new fossil has its third antenodal crossvein identical to $A \times 1$ and $A \times 2$, which is not the case in this last family (Zeiri et al., 2015; Nel, 2020). Also, the hind wing vein PsA of the new fossil is not oblique as in the extant Libellulidae, but also different from that in the Urolibellulidae.
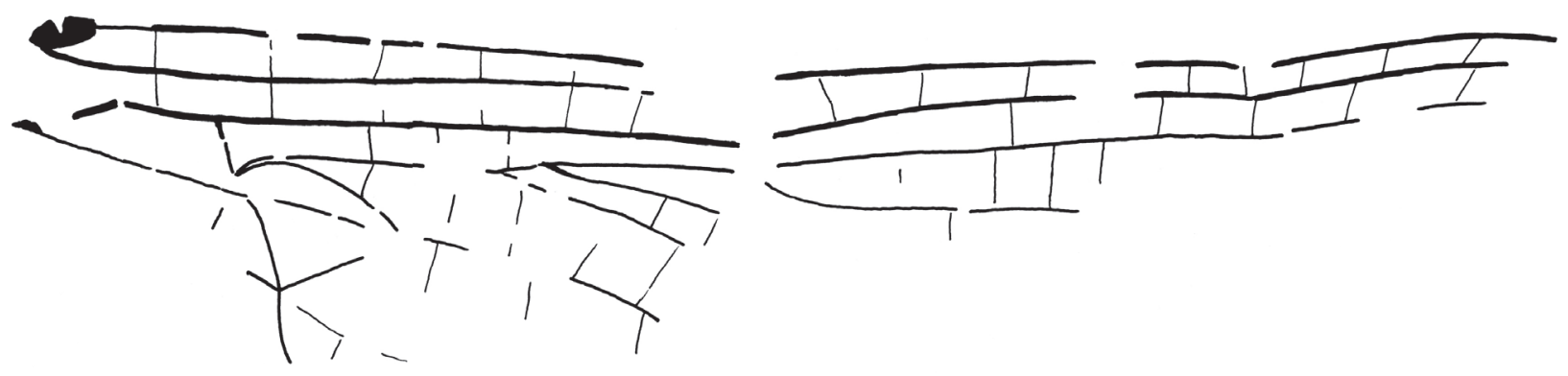

FIGURE 8. Probably a stem-Libellulidae, PE 2001/5195-LS, interpretative drawing of hind wing. Scale bar is $10 \mathrm{~mm}$. 

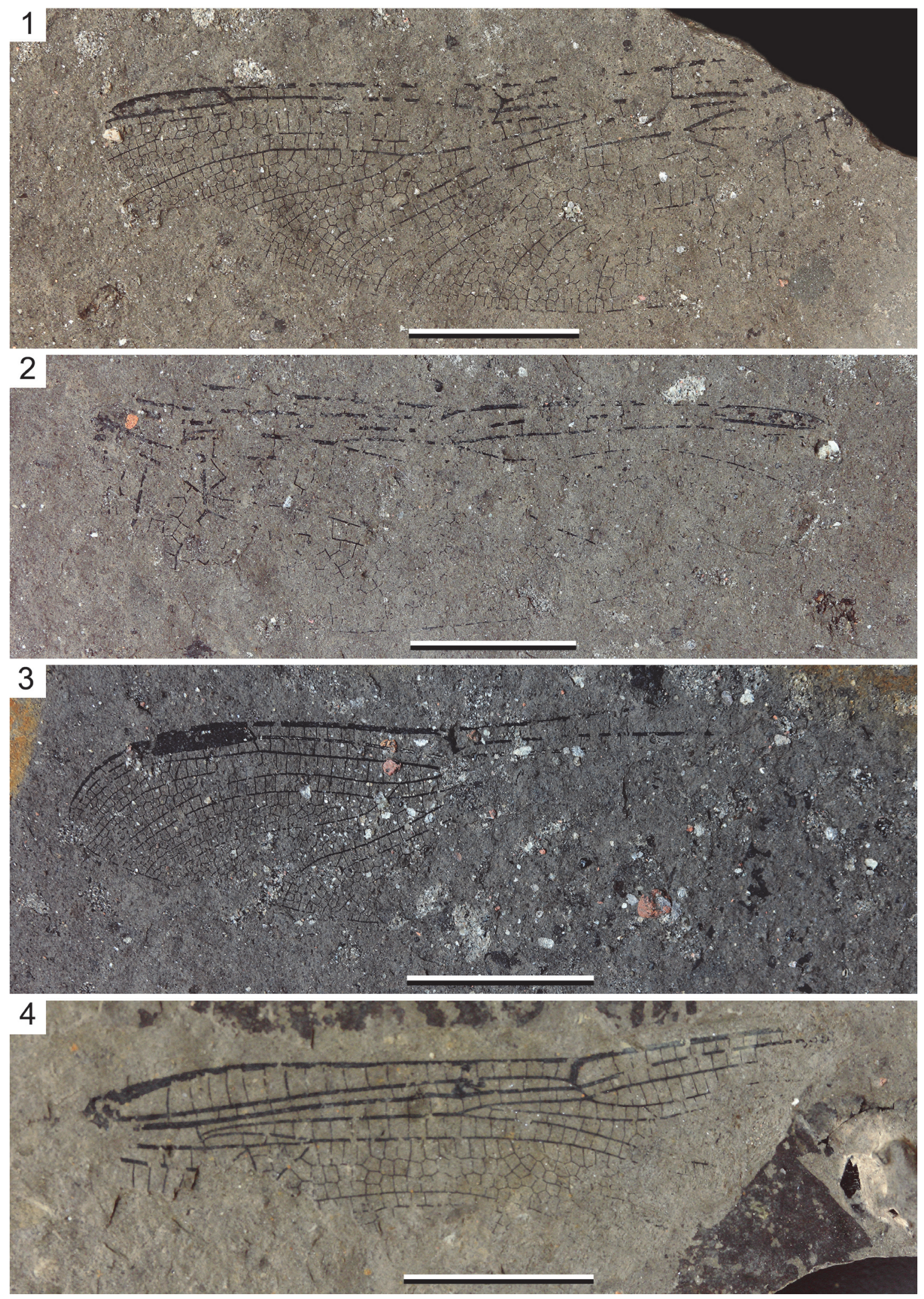

FIGURE 9. Ictinogomphus engelorum sp. nov. 1, Holotype PE 2000/5006-LS a, hind wing; 2, Counterpart of holotype, PE 2000/5006-LS b; 3, Paratype, PE 2003/5039-LS a, distal part of wing; 4, Paratype, PE 2003/5040-LS, part of forewing. Scale bars are $10 \mathrm{~mm}$. 
1

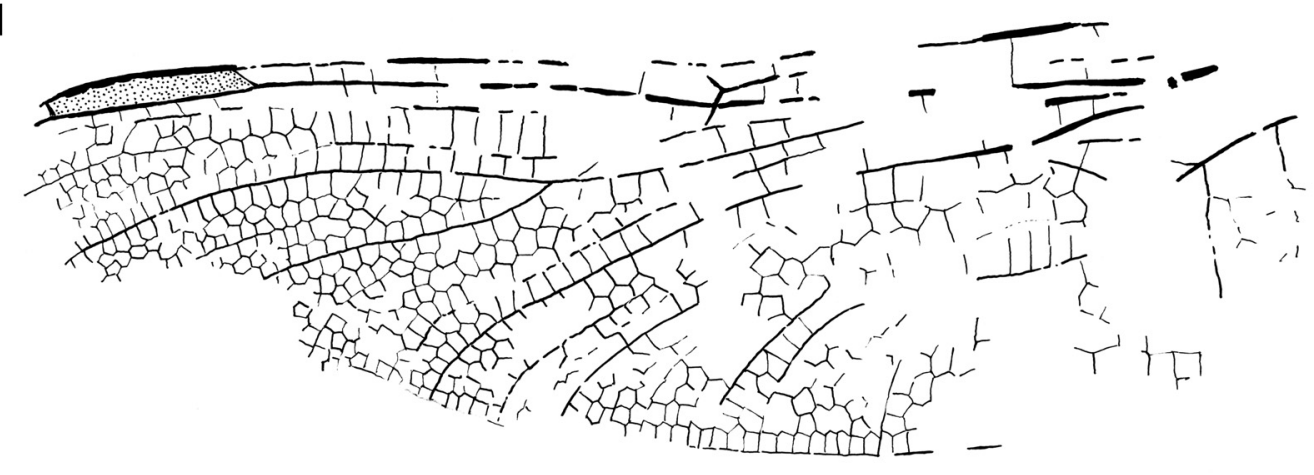

2

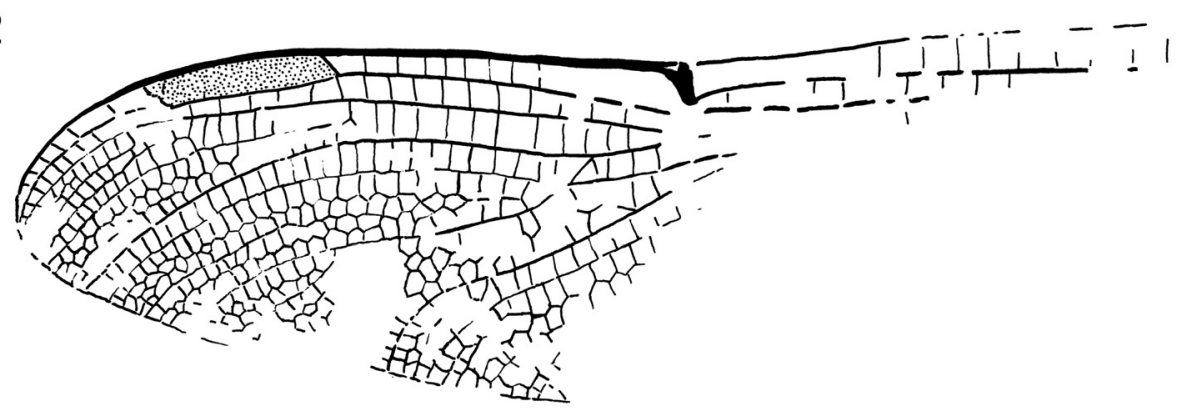

3

FIGURE 10. Ictinogomphus engelorum sp. nov., interpretative drawings of wings. 1, Holotype PE 2000/5006-LS a, hind wing; 2, Paratype, PE 2003/5039-LS a, distal part of wing; 3, Paratype, PE 2003/5040-LS, part of forewing. Scale bars are $10 \mathrm{~mm}$.

Thus, despite its incompleteness, that forbids us to name it, this new fossil probably belongs to the stem group of the Libellulidae.

Several representatives of the crown Libellulidae are recorded from the Oligocene of Europe (Nel and Paicheler, 1993; Nel et al., 1995, 1997, 2005), and the oldest record of the family is from the Late Cretaceous (Fleck et al., 1999). Nevertheless, the clade Libellulida is nearly unrecorded from the Paleocene and the Eocene, with only one fossil found in the earliest Eocene amber of France (Fleck et al., 2000). Thus, the present fossil is of great interest because it shows that representatives of the stem group of the Libellulidae were still present in the Late Oligocene.

Family GOMPHIDAE Rambur, 1842

Subfamily LINDENIINAE Jacobson and Bianchi, 1905 
Nel, Poschmann, \& Wedmann: Odonata from Enspel

\section{Genus ICTINOGOMPHUS Cowley, 1934 (sensu lato, see below) \\ Ictinogomphus engelorum sp. nov. \\ Figures 9-10 \\ zoobank.org/EE23E6B8-F66E-4465-9B46-D743CCDDC312}

Type material. Holotype PE 2000/5006-LS a, b (part and counterpart of a nearly complete hind wing with extreme apex and base missing), paratype PE 2003/5040-LS (part only, basal two-third of a forewing), paratype PE 2003/5039-LS a, b (part and counterpart of distal half of a wing), stored at the State Collection of Natural History of Rhineland-Palatinate.

Diagnosis. Wing characters only. A broad area between posterior branch of IR2 and RP3/4 with three rows of cells in the narrowest part: broad area between two branches of IR2 with three rows of cells basal of secondary longitudinal vein; a long well-defined secondary vein between branches of IR2; hind wing subtriangle free; forewing one probably two-celled; forewing discoidal triangle fivecelled, with costal side distinctly longer than basal side; in hind wing, one row of cells between IR2 and RP2 below pterostigma.

Etymology. Named after Carmen Engel and the entire Engel family from Enspel, for their continuous interest in and support of the excavations.

Description. Holotype PE 2000/5006-LS a, b (Figures 9.1-2, 10.1): Hind wing, hyaline, $46.7 \mathrm{~mm}$ long, wing $13.3 \mathrm{~mm}$ wide; pterostigma $7.1 \mathrm{~mm}$ long, $1.1 \mathrm{~mm}$ wide, covering six cells; pterostigmal brace strong and oblique; 12 postnodals; distance between nodus and pterostigma $15.6 \mathrm{~mm}$, between nodus and arculus $15.6 \mathrm{~mm}$; Ax2 at level of distal angle of discoidal triangle; possibly one crossvein in hypertriangle; discoidal triangle elongate, crossed by a vein, with distal side MAb slightly angled at base of trigonal planate tspl; tspl rather weak and short; 4-5 crossveins in area between RP and MAa basal of RP3/4; probably numerous antenodals, but many are not preserved; 4-5 Bqs crossveins; oblique crossvein ' $O$ ' four cells distal of subnodus; IR1 basally zigzagged, and straight in distal part; base of RP2 aligned with subnodus, RP2 regularly curved without marked concavity; main branch of IR2 parallel to RP2; posterior branch of IR2 well-defined with four rows of cells and a well-defined secondary longitudinal vein between it and main branch; three rows of cells between posterior branch of IR2 and RP3/4 in narrower part; RP3/4 smoothly curved but with a more pronounced curve apically; one row of cells between RP3/4 and MAa, but near their apices a zigzagged vein and two rows of cells in-between;
MAa smoothly curved; a posterior branch of MAa similar to that of IR2; postdiscoidal area with two rows of cells basally and distally greatly broadened; mostly one row of cells between MP and $\mathrm{CuAa}$, but two rows near posterior wing margin; cubito-anal area broad with 6-7 rows of cells between $\mathrm{CuAa}$ and posterior wing margin and 4-5 posterior branches of $\mathrm{CuAa}$; anal area poorly preserved, anal loop apparently subdivided into four cells; subtriangle free; PsA well-defined and oblique; median area free; submedian crossed by CuP and another vein.

Paratype PE 2003/5039-LS a (Figures 9.3, 10.2): As the basal third is missing, it is not possible to determine if it is a fore- or a hind wing. Preserved parts are very similar to those of specimen PE 2000/5006-LS. Only IR1 is slightly shorter than in PE 2000/5006-LS, only four rows of cells between the branches of IR2, and 11 postnodals. Pterostigma $6.7 \mathrm{~mm}$ long, $1.1 \mathrm{~mm}$ wide, distance between nodus and pterostigma $10.5 \mathrm{~mm}$.

Paratype PE 2003/5040-LS (Figures 9.4, 10.3): Forewing, hyaline; length of fragment $38.6 \mathrm{~mm}$; wing ca. $9.8 \mathrm{~mm}$ wide; distance from base to arculus $4.5 \mathrm{~mm}$, from arculus to nodus $19.8 \mathrm{~mm}$, from base to $A x 12.7 \mathrm{~mm}$, from $A \times 1$ to $A \times 26.3 \mathrm{~mm}$; $A x 2$ slightly basal to distal angle of discoidal triangle; five crossveins between $A x 1$ and $A x 2,15$ secondary antenodal crossveins distal of $A \times 2$; 14 preserved postnodals; 12 crossveins between RP and MAa basal of RP3/4; seven Bqs veins; oblique vein 'O' five cells distal of subnodus; hypertriangle with two crossveins; discoidal triangle subdivided into five cells, with costal side $3.2 \mathrm{~mm}$ long, basal side $2.5 \mathrm{~mm}$ long, distal side MAb $3.2 \mathrm{~mm}$ long, MAb with a slight angle at base of tspl; RP3/4 and MAa weakly curved and parallel in preserved parts, with one row of cells in-between; three rows of cells in basal part of postdiscoidal area, broadened distally; a distinct posterior branch of MAa, with four rows of cells between it and MAa; median area free; submedian area crossed by CuP and two other veins; PsA strong and oblique; subtriangle possibly crossed by a vein (fragment visible).

Remarks. The preserved parts of these three wings are very similar, and the forewing and the hind wing fit well with a Gomphidae of the genus Ictinogomphus Cowley, 1934. Probably all wings are of the same species. The attribution to the family Gomphidae is suggested by the following synapomorphies: distinct PsA; slight angle in the posterodistal side of the discoidal triangle caused by the presence of the tspl; anterior side of the hypertriangle distinctly curved; straight arculus 
(Bechly, 1996, 2003). Ictinogomphus engelorum sp. nov. shows an elongated discoidal triangle with a distinct tspl, which is a feature only known within Gomphidae from the Hageniinae and Lindeniinae. The Hageniinae have the veins MP and CuAa strongly divergent towards the wing margin in their hind wings; IR1 is secondarily elongated in both wings; costal margin and RA is not widened along pterostigmata. All these characters are not present in Ictinogomphus engelorum sp. nov. Also, the Hageniinae have the discoidal triangles distinctly longitudinal elongate in both pairs of wings, which is not the case for the forewing. The Lindeniinae are characterized by the following synapomorphies: secondary branch of IR2 very distinct, therefore IR2 appears to be dichotomously forked distal of the lestine oblique vein; hind wing discoidal triangle longitudinal elongate with a strongly sigmoidal and angulated distal side, caused by the development of a distinct tspl in the postdiscoidal area; discoidal triangles divided into more than two cells in both pairs of wings; in forewings the basal part of the subdiscoidal cell (between CuP-crossing and pseudo-anal vein PsA) is traversed by supplementary cubito-anal-crossveins; pseudo-anal vein PsA is less distinct in the hind wing, correlated with the elongated hind wing discoidal triangle; hypertriangle divided by at least two or more crossveins.

Among the Recent lindeniine genera, Diastatomma Burmeister, 1839, has a pronounced angle in the forewing distal side (MAb) of discoidal triangle, strongly curved distal halves of main longitudinal veins, and many more cells covered by the pterostigmata, unlike Ictinogomphus engelorum sp. nov. (Schouteden, 1934; Dijkstra and Clausnitzer, 2014). Lindenia De Haan, 1826, has also a pronounced angle of MAb, a more elongate discoidal triangle of forewing, and a narrower apical part of the area between RP3/4 and MAa than Ictinogomphus engelorum sp. nov. Gomphidictinus Fraser, 1942, differs from Ictinogomphus engelorum sp. nov. in the absence of the pterostigmal brace, in numerous small cells covered by the pterostigmata and in the three-celled hind wing subtriangle (Carle, 1986; Zhang et al., 2017). The venation of Gomphidia Selys, 1854 (incl. Mitragomphus Needham, 1944), resembles that of Ictinogomphus engelorum sp. nov., but the pterostigmal braces are reduced, and the forewing discoidal triangle is more equilateral than in Ictinogomphus engelorum sp. nov., although subject to some variation (Needham, 1944; Garrison et al., 2015; Zhang et al., 2017; Babu and Subramanian, 2019). Cacoides
Cowley, 1934 shares with Ictinogomphus engelorum sp. nov. the presence of three rows of cells between RP3/4 and posterior branch of IR2, several crossveins in the area between RP and MAa basal of RP3/4, but it differs from Ictinogomphus engelorum sp. nov. in the equilateral forewing discoidal triangle, a marked concavity of the vein RP2, and a longer pterostigma, covering much more cells (Schmidt, 1935: pl. 17, fig. 5; Garrison et al., 2010). Melanocacus Belle, 1986, also differs from Ictinogomphus engelorum sp. nov. in the equilateral forewing discoidal triangle and a longer pterostigma, covering many more cells (Belle, 1986).

The four Recent genera Ictinogomphus, Austrictinogomphus Fraser, 1940, Sinictinogomphus Fraser, 1939, and Indictinogomphus Fraser, 1939, can be accurately separated on the basis of the genitalia only (Fraser, 1939). Carle (1986: 320) indicated that Austrictinogomphus, Cinitogomphus Pinhey, 1964, Indictinogomphus, and Sinictinogomphus could be subgenera of Ictinogomphus. Only this group of genera would greatly resemble Ictinogomphus engelorum sp. nov. Nevertheless, Ictinogomphus engelorum sp. nov. differs from the African genus Cinitogomphus in the forewing discoidal triangle with the costal side longer than the basal side, not right angled isosceles (Pinhey, 1964, 1970). In Ictinogomphus engelorum sp. nov., this triangle is isosceles in having costal and distal sides of the same lengths, not the basal and costal sides. The monotypic genus Austrictinogomphus has only two rows of cells in the postdiscoidal area, but the variability of this character remains unknown (Fraser, 1940). It is not possible to discriminate among the three other genera Ictinogomphus, Sinictinogomphus, and Indictinogomphus. We can only indicate that Ictinogomphus engelorum sp. nov. corresponds to an Ictinogomphus sensu lato. The presence of three rows of cells in area between RP3/4 and posterior branch of IR2 in Ictinogomphus engelorum sp. nov. seems to be unusual in the genus Ictinogomphus. At least Cinitogomphus dundoensis, Ictinogomphus alaquopterus, $I$. angulosus, I. australis, possibly $I$. distinctus, I. kishori and I. celebensis, I. decoratus, I. dobsoni, I. ferox, I. fraseri, I. paulini, I. pertinax, I. pugnovittatus, I. rapax, I. regis-alberti, and I. tenax have only two rows of cells in this area (Schmidt, 1935; Ram, 1985).

Among the fossil Lindeniinae, the oldest representative Cratolindenia knuepfae Bechly, 2000, is from the Early Cretaceous of Brazil. It strongly differs from Ictinogomphus engelorum sp. nov. in a 
more distal position of the posterior branch of IR2, in a strongly oblique pterostigmal brace and in having a very broad area between RP2 and RP1 below the pterostigma. Schädel and Bechly (2016) described Burmalindenia imperfecta based on the basal parts of hind wings from the 'mid'-Cretaceous Burmese amber, and attributed it to the 'subfamily cf. Lindeniinae'. It differs from Ictinogomphus engelorum sp. nov. in the strongly curved veins $A A 1 b$ and $\mathrm{CuAb}$.

Hagen (1863) described Ictinogomphus fur from the Oligocene of Rott am Siebengebirge (Germany), on the basis of the basal third of a wing. The elongate vein CuAb would suggest it is a hind wing; but if this is correct, the presence of three cells in the subdiscoidal area does not fit with an Ictinogomphus in which this area is unicellular (Frazer, 1957). Indeed, the shape of the discoidal triangle better corresponds to that of a forewing. Nel and Paicheler (1994a) already indicated that it is an Anisoptera of uncertain family that should be revised.

Nel and Paicheler (1994a) described an undetermined Lindeniinae from the latest Oligocene of Bes-Konak (Turkey). Also Prokop et al. (2016) described an ?/ctinogomphus species indet. from the early Oligocene of Seifhennersdorf (Saxony, Germany) on the basis of the distal two-third of a forewing. Ictinogomphus engelorum sp. nov. differs from these two fossils in the broader area between posterior branch of IR2 and RP3/4 with three rows of cells in the narrowest part, instead of two, the broader area between the two branches of IR2 with three rows of cells basal of the secondary longitudinal vein instead of two, and the longer and better defined secondary vein between the branches of IR2.

Schädel and Lechner (2017) described Ictinogomphus hassleri from the early Miocene of Carinthia (Austria), on the basis of the distal two-third of a hind wing. Ictinogomphus engelorum sp. nov. differs from $I$. hassleri in the presence of three rows of cells between RP3/4 and posterior branch of IR2 instead of two, and in the presence of only one row of cells between IR2 and RP2, instead of two, below the pterostigma.

Schädel and Lechner (2017: 157) indicated that Ictinogomphus hassleri can be separated from the other lindeniine genera, except Ictinogomphus and Sinictinogomphus Fraser, 1939, by the 'shape of the triangulum and the position of the Tspl-origin', without being more precise. But the preserved parts of the wing of $I$. hass/eri are nearly identical to those of the Recent Gomphidia podhigai Babu and
Subramanian, 2019, without perceptible differences in the discoidal triangle, position of the angle of MAb and shape of the trigonal planate (Babu and Subramanian, 2019: fig. 9).

Yasuno (1990) attributed an abdomen with characteristic lateral expansions from the Miocene of Japan to the genus Ictinogomphus. It is not possible to compare it to Ictinogomphus engelorum sp. nov., and its attribution to a lindeniine genus is not possible.

Suborder ZYGOPTERA Selys, 1854 or

EPIPROCTOPHORA Bechly, 1996

Stem group of family SIEBLOSIIDAE Handlirsch, 1907

Genus OLIGOLESTES Schmidt, 1958

Type species. Lestes grandis Statz, 1935 (Oligocene, Rott am Siebengebirge, Germany).

Other species. Oligolestes stoeffelensis sp. nov. (Oligocene, Enspel, Germany).

Oligolestes stoeffelensis sp. nov. Undetermined Zygoptera (Wedmann, 2000: 15, pl. 9, fig. 1)

Figure 11

zoobank.org/3D348180-21EC-4BA1-871F-D994E84952F4

Type material. Holotype PE 1995/9164-LS (compression fossil of a rather well-preserved body with the three basal abdominal segments and bases of the four wings), stored at the State Collection of Natural History of Rhineland-Palatinate.

Diagnosis. Wing with a narrow area between CuA and posterior wing margin with two rows of cells.

Etymology. Named after the mined and now disappeared Stöffel hill, that once covered the sediments of paleolake Enspel.

Description. Head visible from frontal, hammershaped, with globular eyes well-separated, $4.6 \mathrm{~mm}$ wide, dark; meso-metathorax $9.3 \mathrm{~mm}$ long, $4.7 \mathrm{~mm}$ high, dorsally green-blue metallic; abdomen dorsally green-blue metallic, ventrally dark; second segment with secondary male genital apparatus; only parts of the wings between their bases and nodi preserved, $19.1 \mathrm{~mm}$ long, petiole of wings 4.8 $\mathrm{mm}$ long; distance from base to arculus $5.8 \mathrm{~mm}$, from arculus to nodus $4.8 \mathrm{~mm}$; estimated distance between nodus and wing apex $21.3 \mathrm{~mm}$; estimated wing length $32.0 \mathrm{~mm}$; wing $4.9 \mathrm{~mm}$ wide at level of nodus; Ax1 and Ax2 $2.1 \mathrm{~mm}$ apart; Ax2 aligned with arculus; discoidal cells of fore- and hind wings identical, basal side $0.5 \mathrm{~mm}$ long, costal side 0.9 $\mathrm{mm}$ long, distal side (MAb) $0.9 \mathrm{~mm}$ long, ventral side $13.8 \mathrm{~mm}$ long; ScP kinked at nodus; nodal crossing and subnodus perpendicular to RA and RP1/2, respectively; bases of RP3/4 and IR2 mid- 

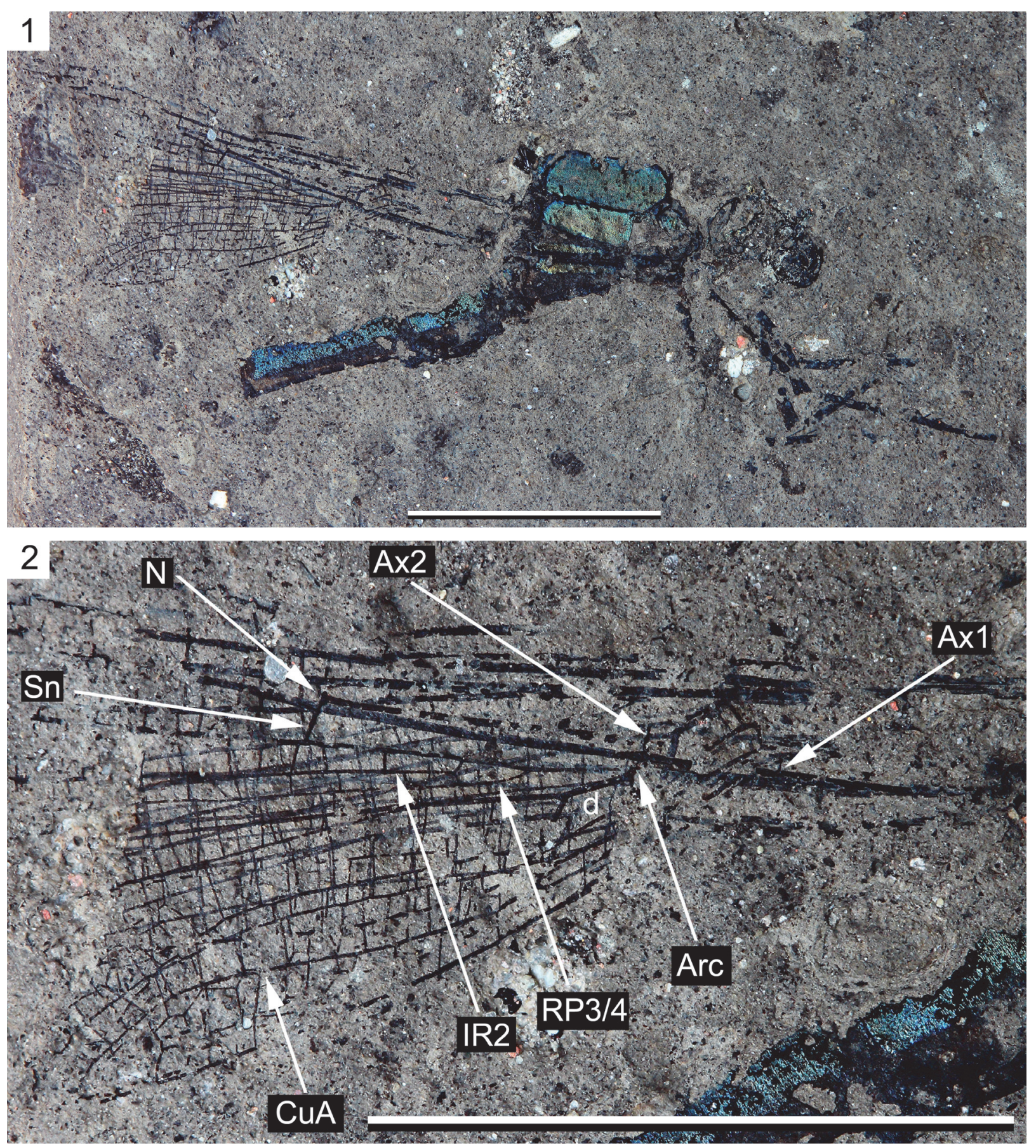

FIGURE 11. Oligolestes stoeffelensis sp. nov., holotype PE 1995/9164-LS. 1, Photograph of habitus; 2, Hind wing, Arc arculus, d discoidal cell, $\mathrm{N}$ nodus, $\mathrm{Sn}$ subnodus. Scale bar is $10 \mathrm{~mm}$.

way between nodus and arculus, that of RP3/4 3.0 $\mathrm{mm}$ distal of arculus, that of IR2 $1.5 \mathrm{~mm}$ of that of $\mathrm{RP} 3 / 4$; one row of cells between RP3/4 and MAa and in postdiscoidal area in preserved parts; CuA strongly curved, ending on posterior wing margin well distal of level of nodus; two rows of cells between $\mathrm{CuA}$ and posterior wing margin.
Remarks. The wing venation of this fossil, although incompletely preserved, is very similar to that of the Oligocene genus Oligolestes in the shape of the discoidal cells, subnodus being perpendicular to RP1/2 and RA, bases of IR2 and RP3/4 located midway between arculus and nodus, arculus opposite $\mathrm{Ax} 2$, curved $\mathrm{CuA}$ with three rows of cells between it and posterior wing 
margin, base of RP2 well distal to subnodus, narrow area between RP3/4 and MAa (Schmidt, 1958: fig. 2). Statz (1935: 12) indicated that the arculus of O. grandis is $5.5 \mathrm{~mm}$ from the wing base but, after the photograph of Schmidt (1958: 3, pl. 1, fig. 1), the wing is broken at base, and thus the petiole is certainly longer than the estimation of Statz. Schmidt added that the wing is $39.0 \mathrm{~mm}$ long, and proposed a reconstruction with an elongate petiole figured with dotted lines. The ratio (wing width at level of nodus/distance nodus to arculus) is 1.05 for the two fossils, suggesting that the other main proportions are also similar. We calculate the estimated distance between the nodus and the wing apex of Oligolestes stoeffelensis sp. nov. after its ratio with the distance between arculus and nodus compared to that of $O$. grandis; and thus we could establish an estimation of the total wing length of O. stoeffelensis sp. nov., which would be ca. 32 $\mathrm{mm}$, thus it is distinctly smaller than $O$. grandis. The ratio (distance nodus to arculus/width cubital area) is 3.3 for 0 . grandis while it is 4.3 in 0 . stoeffelensis sp. nov., corresponding to a narrower cubital area in the latter.

The exact phylogenetic position of the genus Oligolestes remains somewhat enigmatic, although $\mathrm{Nel}$ et al. (2005a) considered it as belonging to the stem group of the Cenozoic family Sieblosiidae. The Sieblosiidae sensu stricto are characterized by the presence of a highly specialised nodus apparently traversed by ScP, as the terminal kink of CP is shifted basally together with the nodal and subnodal veinlets and the nodal membrane sclerotisation is reduced. Such structure is only present, among the Odonata, in the Mesozoic anisopteran family Aeschnidiidae. Our fossil, O. grandis, and Italolestes $\mathrm{Nel}$ et al., 2005, have a ScP making a kink in the nodus as in the other Odonata. Italolestes differs from our fossil and $O$. grandis in the nodal crossing and subnodus of 'normal' obliquity (Nel et al., 2005a-b; Nel and Fleck, 2012). The Miocene sieblosiid genera Paraoligolestes $\mathrm{Nel}$ and Escuillié, 1993 and Miostenolestes Nel et al., 2005 have a venation also very similar to that of our fossil and $O$. grandis, especially in the rather narrow discoidal cells (compared to those of the Oligocene Sieblosia Handlirsch, 1906, Stenolestes Scudder, 1895, Parastenolestes Nel and Paicheler, 1994b, or the Miocene Germanolestes Nel and Fleck, 2012), but their ScP cross through the nodus (Nel and Escuillié, 1993; Nel and Paicheler, 1994b).

Notice that the current phylogenetic relationships of the Sieblosiidae remain uncertain, being either related to the Epiproctophora (the so-called
'Anisozygoptera' + Anisoptera) or to the Zygoptera (see discussion in Fleck et al., 2004).

Oligolestes stoeffelensis sp. nov. is of great interest for the head morphology in Sieblosiidae. In the few sieblosiid specimens with the head preserved, it is deformed due to the projection of the mouthparts and the crushing of the frons (Nel et al., 2005: fig. 11). This phenomenom is quite frequent among the fossil Zygoptera ( $\mathrm{Nel}$ and Papazian, 1985: figs. $1-4$; but see also http://mediaphoto.mnhn.fr/media/15184399435421FO8gTE-

JGLR9en8s or http://mediaphoto.mnhn.fr/media/ 15184399443786A3TS35XORz2fEVq) or even in the Tarsophlebiidae (sister-group of Odonata) (Fleck et al., 2014: fig. 1). In the case of Oligolestes stoeffelensis sp. nov., the lateral position of the body together with the rotation of the head have led to the absence of frontal projection of the mouthparts and to a minimal deformation of the head. It clearly confirms that the head of the Sieblosiidae is of zygopteran hammer-type.

Oligolestes stoeffelensis sp. nov. is also of great interest because it has the dorsal surface of the thorax and abdomen green-blue metallic (probably physical colors, as it can be frequently observed in fossil insects preserved in diatomites), a character that was unknown for the other Sieblosiidae. Preservation of metallic structural colors in Enspel insects was hitherto primarily known from exceptionally well-preserved beetle fossils (e.g., Wedmann, 2000, Wedmann et al., 2010, McNamara, 2013; Penney and Jepson, 2014: figs 46-48).

\section{NAIADS FROM PALEOLAKE ENSPEL}

Brockhaus et al. (2020) described several naiads attributed to the Lindeniinae from paleolake Enspel, being likely more closely related to Gomphidia or Ictinogomphus than to any other genera of the subfamily. The present discovery of an adult Ictinogomphus confirms the presence of this group in this paleolake, and the probable correspondence between these naiads and the adult of $I$. engelorum sp. nov. These dragonflies were probably autochthonous in this paleolake. This new species also confirms the presence and diversity of the Lindeniinae in the Oligocene-Miocene of Europe.

Wedmann et al. (2010: fig. 6a) figured a naiad of a 'possibly Aeshnidae' from Enspel. This naiad clearly belongs to the Aeshnidae because of the long terminal spine-like abdominal appendages, long abdomen with lateral spines on the last segments, shape of the eyes and head very similar to 

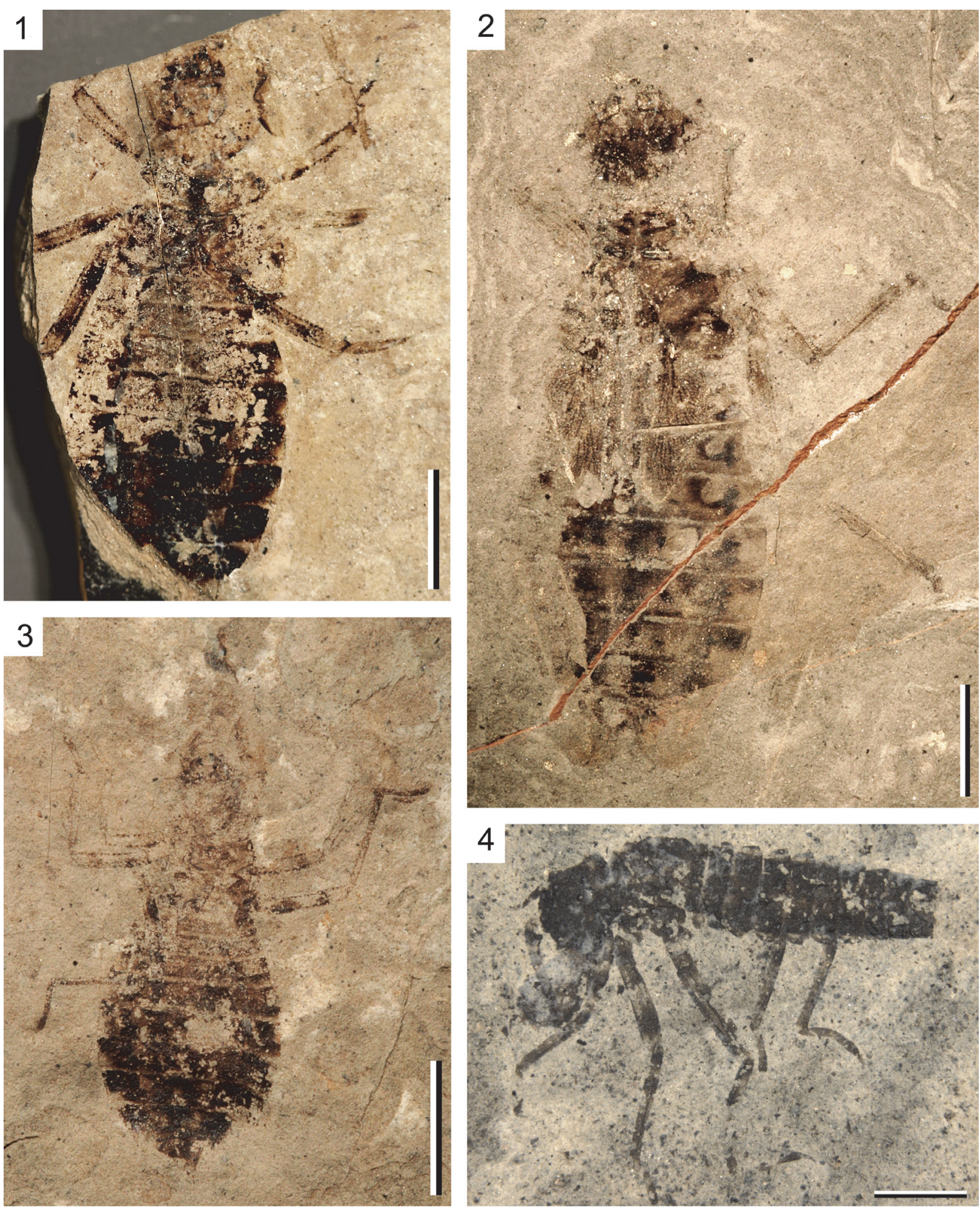

FIGURE 12. Naiads of Odonata from paleolake Enspel. 1-3, Naiads attributable to the libelluloid clade. 1, PE 2006/ 5022-LS; 2, PE 2010/5637-LS; 3, PE 2010/5657-LS; 4, PE 2010/5637-LS, a zygopteran naiad. Scale bars are $5 \mathrm{~mm}$ (1-3), $2 \mathrm{~mm}(4)$. 
those of extant Aeshna. Unfortunately, the wing pad trachea are too poorly preserved to allow an attribution to a precise genus. It can only be considered as an aeshnid naiad, possibly of the last stage, because of the long wing pads.

Several naiads (PE 2006/5022-LS, PE 2010/ 5657-LS, PE 2010/5637-LS) are attributable to the libelluloid clade (Figure 12.1-3). Their masks are too poorly preserved to be studied. Only the wing pads of PE 2010/5637-LS show very well-preserved trachea (Figure 12.2). The anal loop is clearly visible, elongate toe-shape, typical of the crown group of the Libellulidae. This naiad seems to have a dorsal aperture on the thorax, suggesting it could be an exuvia.

One undescribed naiad is attributable to the suborder Zygoptera (PE 2013/5018-LS, Figure 12.4). Although incomplete, the shape of the mask and body remind of Lestidae. In addition to the remains of the adult specimen of Oligolestes stoeffelensis sp. nov., this naiad is the only record of damselflies from paleolake Enspel.

\section{CONCLUSION}

The specimens described herein significantly add to the biodiversity of the Odonata fauna of the late Oligocene paleolake of Enspel, which is shown to be quite diverse comprising at least two species of Aeshnidae, one Gomphidae (adult and naiads), one Macromiidae (Brockhaus et al., 2020), a stem Libellulidae, a crown Libellulidae (naiad), a stem Sieblosiidae of the genus Oligolestes, and a zygopteran naiad possibly of the families Lestidae or Sieblosiidae. The genera Oligaeschna, Epiaeschna, and Ictinogomphus were already recorded from other European outcrops. The presence of a stem Sieblosiidae is especially interest- ing because this family is currently only known from Eurasian Oligocene-Miocene paleolakes and seems to be typical of these periods and paleogeographical area (Nel et al., 2005a; Nel et al., 2016). They are not present among the odonatan fauna of the Eocene of Messel or North America, where they seem to be 'replaced' by other large, damselfly-like Odonata (Garrouste and Nel, 2015).

This high diversity and the presence of many naiads suggest the presence of an autochthonous fauna with both naiads and adults of the same species and thus a water oxygenated enough for these nymphs, at least in the shallow water zones near the shores of the paleolake, that was frequently and long enough (several years with respect to Gomphidae) suitable to allow the development of these insects. Furthermore, extant Aeshnidae and Macromiidae are fast and enduring fliers and thus the representatives of these families were potential 'hawker predators' patrolling the open spaces along the shores of palaeolake Enspel when foraging. In contrast, Sieblosiidae, Libellulidae, and Gomphidae tend to be less persistent fliers and preferentially represent the 'percher' type of predator. This suggests that there was some niche partitioning among the dragonflies of paleolake Enspel indicating a well-structured ecosystem.

\section{ACKNOWLEDGEMENTS}

We sincerely thank two anonymous referees for their useful remarks on the first version of the paper. We are very grateful to P. Schäfers and K. Nungesser (both GDKE, Direktion Landesarchäologie/Erdgeschichte, Mainz) for providing fossils in their care. T. Brockhaus (Jahnsdorf) and M. Schorr (Zerf) kindly helped with hard to get literature.

\section{REFERENCES}

Babu, R. and Subramanian, K.A. 2019. A new species of Gomphidia Selys, 1854 (Insecta: Odonata: Anisoptera: Gomphidae) from the Western Ghats of India. Zootaxa, 4652:155-164. https://doi.org/10.11646/zootaxa.4652.1.9

Bechly, G. 1996. Morphologische Untersuchungen am Flügelgeäder der rezenten Libellen und deren Stammgruppenvertreter (Insecta; Pterygota; Odonata), unter besonderer Berücksichtigung der Phylogenetischen Systematik und des Grundplanes der Odonata. Petalura Special Volume, 2:1-402.

Bechly, G. 2000. Two new fossil dragonfly species (Insecta: Odonata: Pananisoptera: Aeschnidiidae and Aktassiidae) from the Solnhofen lithographic limestones (Upper Jurassic, Germany). Stuttgarter Beiträge zur Naturkunde B, 288:1-9.

Belle, J. 1986 New World Lindeniinae, with Melanocacus interioris gen. nov, spec. nov. (Odonata: Gomphidae). Entomologische Berichte, 46:97-102. 
Brockhaus, T., Müller, O., Nel, A., Poschmann, M.J., and Wappler, T. 2020. Fossil dragonflies (Odonata: Anisoptera) from the late Oligocene Fossil-Lagerstätte Enspel (RhinelandPalatinate, SW-Germany). Palaeoentomology, 3:284-300. https://doi.org/10.11646/palaeoentomology.3.3.9

Carle, F.L. 1986. The classification, phylogeny and biogeography of the Gomphidae (Anisoptera). I. Classification. Odonatologica, 15:275-326.

Cockerell, T.D.A. 1913. Two fossil insects from Florissant with a discussion of the venation of the aeschnine dragon-flies. Proceedings of the United States National Museum, 45:577-583.

de Selys-Longchamps, E. 1883. Synopsis des Aeschnines. Première partie: classification. Bulletin de l'Académie Royale des Sciences, des Lettres et des Beaux-Arts de Belgique, 5:712-748.

Dijkstra, K.-D.B. and Clausnitzer, V. 2014. The dragonflies and damselflies of Eastern Africa. Handbook for all Odonata from Sudan to Zimbabwe. Studies in Afrotropical Zoology, 298:1264.

Fabricius, J.C. 1793. Entomologia systematica emendate et aucta. Secundum classes, ordines, genera, species adjectis synonimis, locis, observationibus, descriptionibus. Tome 2. C. G. Proft, Hafniae.

Fleck, G., Bechly, G., Martínez-Delclòs, X., Jarzembowski, E.A., and Nel, A. 2004. A revision of the Mesozoic dragonfly family Tarsophlebiidae, with a discussion on the phylogenetic positions of the Tarsophlebiidae and Sieblosiidae (Odonatoptera: Panodonata). Geodiversitas, 26:33-60.

Fleck, G., Nel, A., De Plöeg, G., and Masselot, G. 2000. A fossil dragonfly from the lowermost Eocene amber of France (Insecta, Odonata, Anisoptera). Acta Geologica Hispanica, 35:131134.

Fleck, G., Nel, A., and Martínez-Delclòs, X. 1999. The oldest record of the Libellulidae from the Upper Cretaceous of Kazakhstan (Odonata, Anisoptera). Cretaceous Research, 20:655658. https://doi.org/10.1006/cres.1999.0166

Fraser, F.C. 1939. A note on the generic characters of Ictinogomphus Cowley (Odonata). Proceedings of the Royal Entomological Society of London B, 8:21-24.

Fraser, F.C. 1940. A comparative study of the penes of the family Gomphidae. Transactions of the Royal Entomological Society of London, 90:541-550.

Garrison, R.W., Dijkstra, K.D.B., Hämäläinen, M., and Villanueva, R.J.T. 2015. Mitragomphus ganzanus Needham, 1944, a geographically misplaced dragonfly, is a junior synonym of Gomphidia kirschii Selys, 1878 (Odonata: Gomphidae). Zootaxa, 3911:280-286. https://doi.org/10.11646/zootaxa.3911.2.9

Garrison, R.W., von Ellenrieder, N., and Louton, J.A. 2010. Damselfly Genera of the New World. An Illustrated and Annotated Key to the Zygoptera. The John Hopkins University Press, Baltimore.

Garrouste, R. and Nel, A. 2015. New Eocene damselflies and first Cenozoic damsel-dragonfly of the isophlebiopteran lineage (Insecta: Odonata). Zootaxa, 4028:354-366. https://doi.org/10.11646/zootaxa.4028.3.2

Gaudant, J. 1993. Nouvelles recherches sur l'ichthyofaune oligo-miocène du Puy de Mur (Puyde-Dome). Géologie de la France, 1993:25-37.

Hagen, H.A. 1863. Neuroptern aus der Braunkohle von Rott im Siebengebirge. Palaeontographica, 10:247-269.

Huang, D.Y. and Nel, A. 2009. First fossil record of a Lindeniidae from the Miocene Shanwang Formation of China (Odonata, Anisoptera, Lindeniidae). Bulletin de la Société Entomologique de France, 114:441-443.

Jacquelin, L., Desutter-Grandcolas, L., Chintauan-Marquier, I., Boistel, R., Zheng, D., Prokop, J., and Nel, A. 2018. New insights on basivenal sclerites using 3D tools and homology of wing veins in Odonatoptera (Insecta). Scientific Reports, 8:1-7. https://doi.org/10.1038/s41598-017-18615-0

Leach, W.E. 1815. Entomology, p. 57-172. In Brewster, D. (ed.), The Edinburgh Encyclopaedia 9.

Li, Y.J., Nel, A., Ren, D., Zhang, B.I., and Pang, H. 2011. New discoveries of Neogene hawker dragonflies (Insecta, Odonata, Aeshnidae) from Shandong province in China. Zoosystema, 33:577-590. https://doi.org/10.5252/z2011n4a8

Martin, R. 1908-1909. Aeschnines. Collections zoologiques du Baron Edm. De Selys Longchamps, Catalogue systématique et descriptif, Haye, Brussels 18 \& 19:1-84, 85-156. 
Nel, Poschmann, \& Wedmann: Odonata from Enspel

Martin, R. 1911. Odonata. Fam. Aeschnidae. Subfam. Aeschninae. Genera Insectorum, 115:134.

Martynov, A.V. 1929. Fossil insects from Tertiary deposits in Ashutas Saisan district. Trudy Geologicheskogo Muzeya Akademii nauk SSSR, 5:173-216.

McNamara, M.E. 2013. The taphonomy of colour in fossil insects and feathers. Palaeontology, 56:557-575. https://doi.org/10.1111/pala.12044

Mertz, D.F., Renne, P.R., Wuttke, M., and Mödden, C. 2007. A numerically calibrated reference level (MP28) for the terrestrial mammal-based biozonation of the European Upper Oligocene. International Journal of Earth Sciences (Geologische Rundschau), 96:353-361. https://doi.org/10.1007/s00531-006-0094-6

Needham, J.G. 1944. Further studies on Neotropical gomphine dragonflies. Transactions of the American Entomological Society, 69:171-224.

Nel, A. 2020. The second genus of the extinct dragonfly family Urolibellulidae from the Eocene Green River Formation (Odonata, Anisoptera: Cavilabiata). Palaeoentomology, 3:50-53. https://doi.org/10.11646/palaeoentomology.3.1.7

Nel, A., Arillo, A., and Ortuño, V.M. 1995. Découverte du premier Libellulidae: Trameinae de l'Oligocène d'Espagne (Odonata: Libelluloidea). Bulletin de la Société Entomologique de France, 100:487-488.

$\mathrm{Nel}, \mathrm{A}$. and Escuillié, F. 1993. Découverte d'un nouveau genre de Sieblosiidae dans le Miocène supérieur de l'Ardèche (France) (Odonata, Zygoptera, Lestoidea, Sieblosiidae). Nouvelle Revue d'Entomologie (N.S.), 10:233-242.

Nel, A. and Fleck, G. 2012. A new genus and species of Sieblosiidae from the Middle Miocene of Germany (Odonata: Epiproctophora). Zootaxa, 3582:64-68. https://doi.org/10.11646/zootaxa.3582.1.7

Nel, A. and Fleck, G. 2014. Dragonflies and damselflies (Insecta: Odonata) from the Late Eocene of the Isle of Wight. Earth and Environmental Science, Transactions of the Royal Society of Edinburgh, 104:283-306. https://doi.org/10.1017/S175569101400005X

Nel, A., Martínez-Delclòs, X., Paicheler, J.-C., and Henrotay, M. 1993. Les 'Anisozygoptera' fossiles. Phylogénie et classification (Odonata). Martinia Numéro Hors Série, 3:1-311.

Nel, A., Martínez-Delclòs, X., Papier, F. and Oudard, J. 1997. New Tertiary fossil Odonata from France (Sieblosiidae, Lestidae, Coenagrioniidae, Megapodagrionidae, Libellulidae). Deutsche Entomologische Zeitschrift, 44:231-258. https://doi.org/10.1002/mmnd.19970440210

Nel, A. and Paicheler, J.-C. 1993. Les Libellulidae fossiles. Un inventaire critique (Odon., Anisoptera, Libelluloidea). Entomologica Gallica, 4:166-190.

Nel, A. and Paicheler, J.-C. 1994a. Les Gomphidae fossiles. Un inventaire critique (Odonata, Gomphidae). Annales de la Société Entomologique de France (N.S.), 30:55-77.

Nel, A. and Paicheler, J.-C. 1994b. Les Lestoidea (Odonata, Zygoptera) fossiles: un inventaire critique. Annales de Paléontologie, 80:1-59.

Nel, A. and Papazian, M. 1985. Description d'une nouvelle espèce fossile de Lestes Leach, 1815, du Stampien de Céreste (Alpes-de-Haute-Provence) (Odon. Lestidae). Entomologica Gallica, 1:275-279.

Nel, A. and Petrulevičius, J.F. 2010. Afrotropical and Nearctic genera of Odonata in the French Oligocene: biogeographic and paleoclimatic implications (Insecta: Calopterygidae and Aeshnidae). Annales de la Société Entomologique de France (N.S.), 46:228-236. https://doi.org/10.1080/00379271.2010.10697662

Nel, A., Petrulevičius, J.F., Gentilini, G., and Martínez-Delclòs, X. 2005a. Phylogenetic analysis of the Cenozoic family Sieblosiidae (Insecta: Odonata), with description of new taxa from Russia, Italy and France. Geobios, 38:219-233. https://doi.org/10.1016/j.geobios.2003.10.007

Nel, A., Petrulevičius, J.F., Gentilini, G., and Martínez-Delclòs, X. 2005b. Un nouvel Odonate du Miocène d'Italie (Odonata). Bulletin de la Société Entomologique de France, 110:188.

Nel, A., Petrulevičius, J.F., and Jarzembowski, E.A. 2005c. New fossil Odonata from the European Cenozoic (Insecta: Odonata: Thaumatoneuridae, Aeshnidae, ?Idionychidae, Libellulidae). Neues Jahrbuch für Geologie und Paläontologie Abhandlungen, 235:343-380.

Nel, A., Simov, N., Bozukov, V., and Marinov, M. 2016. New dragonflies and damselflies from Middle Miocene deposits in SW Bulgaria (Insecta: Odonata). Palaeontologia Electronica, 19.3.35A:1-13. https://doi.org/10.26879/642 
Peñalver, E., Nel, A., and Martínez-Delclòs, X. 1996. Insectos del Mioceno inferior de Ribesalbes (Castellón, España): Paleoptera y Neoptera Poli- y Paraneoptera. Treballs del Museu de Geologia de Barcelona, 5:15-95.

Penney, D. and Jepson, J.E. 2014. Fossil Insects. An Introduction to Palaeoentomology. Siri Scientific Press, Manchester, UK.

Pinhey, E. 1964. Dragonflies (Odonata) of the Angola-Congo borders of Rhodesia. Publicações Culturais da Companhia de Diamantes de Angola, 63:97-130.

Pinhey, E. 1970. The status of Cinitogomphus Pinhey (Odonata). Arnoldia Rhodesia, 4:1-5.

Piton, L. and Théobald, N. 1939. Poissons, crustacés et insectes fossiles de l'Oligocène du Puydu-Mur, Auvergne. Mémoires de la Société Scientifique de Nancy, 4:77-123.

Poschmann, M., Schindler, T., and Uhl, D. 2010. Fossil-Lagerstätte Enspel - a short review of current knowledge, the fossil association, and a bibliography. Palaeobiodiversity and Palaeoenvironments, 90:3-20. https://doi.org/10.1007/s12549-009-0017-1

Prokop, J. and Nel, A. 2002. New Tertiary dragonflies from Lower Oligocene of the České středohoři Mts and Lower Miocene of the Most Basin in the Czech Republic (Odonata: Anisoptera). Acta Societatis Zoologicae Bohemicae, 66:141-150.

Prokop, J., Pecharová, M., and Nel, A. 2016. New Cenozoic dragonflies from the Most Basin and Středohoří Complex volcanic area (Czech Republic, Germany). Journal of Natural History, 50:2311-2326. https://doi.org/10.1080/00222933.2016.1193648

Prokop, J., Přikryl, T., Dostál, O., and Nel, A. 2007. Oligaeschna kvaceki sp. nov., a new fossil dragonfly (Odonata: Aeshnidae) from the Middle Oligocene of northern Moravia (Western Carpathians). Geologica Carpathica, 58:181-184.

Ram, R. 1985. Two new species of Ictinogomphus Cowley (Anisoptera: Gomphidae) from India. Proceedings of the First Indian Symposium of Odonatology, p. 175-183.

Riek, E.F. and Kukalová-Peck, J. 1984. A new interpretation of dragonfly wing venation based upon early Upper Carboniferous fossils from Argentina (Insecta: Odonatoidea) and basic character states in pterygote wings. Canadian Journal of Zoology, 62:1150-1166. https://doi.org/10.1139/z84-166

Rousset, C., Jacq, V.A., and Magnan, N. 1996. Reconstitution des conditions paléoenvironnementales du dépôt du soufre oligocène des Camoins, à Marseille (Bouches-duRhône, France); rôle des bactéries dans la constitution et dans l'évolution des sédiments d'une lagune continentale aux eaux sulfatées. Bulletin de la Société Géologique de France, 167:375-388.

Schädel, M. and Bechly, G. 2016. First record of Anisoptera (Insecta: Odonata) from midCretaceous Burmese amber. Zootaxa, 4103:537-549. https://doi.org/10.11646/zootaxa.4103.6.4

Schädel, M. and Lechner, T.S. 2017. Two new dragonflies (Odonata: Anisoptera) from the Miocene of Carinthia (Austria). Zootaxa, 4243:153-164. https://doi.org/10.11646/zootaxa.4243.1.7

Schindler, T. and Wuttke, M. 2010. Geology and limnology of the Enspel Formation (Chattian, Oligocene; Westerwald, Germany). Palaeobiodiversity and Palaeoenvironments, 90:21-27. https://doi.org/10.1007/s12549-009-0014-4

Schindler, T. and Wuttke, M. 2015. A revised sedimentological model for the late Oligocene crater lake Enspel (Enspel Formation, Westerwald Mountains, Germany). Palaeobiodiversity and Palaeoenvironments, 95:5-16. https://doi.org/10.1007/s12549-014-0178-4

Schmidt, E. 1935. Odonata der Deutschen Limnologischen Sunda-Expedition. 1. Imagines. Mit Beschreibungen zweier neuer Ictinus aus Celebes und Neu-Guinea. Archiv für Hydrobiologie Supplement, 13:316-397.

Schmidt, E. 1958. Bemerkungen über Lestiden. 3. Über Oligolestes grandis Statz, 1935 und eine neue Lestes-Art aus dem mittel-Oligozän von Rott im Siebengebirge. Decheniana, 111:1-7.

Schouteden, H. 1934. Pseudonévroptères - Odonates. Catalogue raisonné de la faune entomologique du Congo belge. Annales du Musée du Congo Belge, (Zoologie série 3 section 2), 3:1-83.

Scudder, S.H. 1890. The fossil insects of North America (with notes on some European species). 2. The Tertiary insects. Report of the United States Geological Survey of the Territories, 13:1734.

Statz, G. 1935. Drei neue Insektenarten aus dem Tertiär von Rott am Siebengebirge. Wissenschaftliche Mitteilungen des Vereins für Naturkunde und Heimatkunde in Köln, 1:10 14. 
Storch, G., Engesser, B., and Wuttke, M. 1996. Oldest fossil record of gliding in rodents. Nature, 379:439-441.

Timon-David, J. 1946. Insectes fossiles de l'Oligocène inférieur des Camoins. 3. Description d'une nouvelle espèce d'Odonate. Bulletin de la Société Entomologique de France, 51:9496.

von Ellenrieder, N. 2002. A phylogenetic analysis of the extant Aeshnidae (Odonata: Anisoptera). Systematic Entomology, 27:437-467. https://doi.org/10.1046/j.1365-3113.2002.00190.x

Wedmann, S. 2000. Die Insekten der oberoligozänen Fossillagerstätte Enspel (Westerwald, Deutschland). Systematik, Biostratinomie und Paläoökologie. Mainzer Naturwissenschaftliches Archiv, 23:1-154.

Wedmann, S., Poschmann, M., and Hörnschemeyer, T. 2010. Fossil insects from the Late Oligocene Enspel Lagerstätte and their palaeobiogeographic and palaeoclimatic significance. Palaeobiodiversity and Palaeoenvironments, 90:49-58. https://doi.org/10.1007/s12549-009-0013-5

Yasuno, T. 1990. A fossil dragonfly Ictinogomphus from the Miocene Ito's formation, Fukui prefecture, Central Japan. Bulletin of the Japan Sea Research Institute Kanazawa University, 22:49-54.

Zhang, H., Guan, Z.Y., and Wang, W.Z. 2017. Updated information on genus Gomphidictinus (Odonata: Gomphidae) in China with description of Gomphidictinus tongi sp. nov. Zootaxa, 4344:321-332. https://doi.org/10.11646/zootaxa.4344.2.7 